\title{
Fluctuations in biosiliceous production and the generation of Early Cretaceous oceanic anoxic events in the Pacific Ocean (Shatsky Rise, Ocean Drilling Program Leg 198)
}

\author{
Stuart A. Robinson and Trevor Williams \\ Lamont-Doherty Earth Observatory, Columbia University, Palisades, New York, USA
}

Paul R. Bown

Department of Earth Sciences, University College London, London, UK

Received 23 January 2004; revised 21 September 2004; accepted 6 October 2004; published 17 December 2004.

[1] Integration of geophysical logs with sedimentological, biostratigraphic, and physical properties data from poorly recovered chert-rich sequences at Ocean Drilling Program Leg 198 Sites 1207 and 1213 allows us to propose an Aptian-Albian (Early Cretaceous) depositional history for Shatsky Rise (North Pacific Ocean). The logs indicate that the lower Aptian and lower Albian deposits are relatively lithified and unporous compared to contiguous sediments. These characteristics are best explained by increased siliceous cementation that resulted from an elevated flux of radiolarians to the seafloor. The intervals of increased biosiliceous production may record a biotic response to enhanced nutrient delivery, coeval with (but longer in duration than) oceanic anoxic events (OAEs) 1a (early Aptian) and 1b (early Albian). On Shatsky Rise, OAE 1a is represented by organiccarbon-rich sediments, but OAE $1 \mathrm{~b}$ is not. Thus "black shale" deposition in the Pacific Ocean was only possible when a "carbon-burial threshold" was crossed. We speculate that this threshold was related to the balance between productivity and carbon oxidation and that, ultimately, the supply of biolimiting nutrients through hydrothermal alteration of basalt may have been the key to the development of "black shale" in the Pacific basin. INDEX TERMS: 0915 Exploration Geophysics: Downhole methods; 1635 Global Change: Oceans (4203); 3022 Marine Geology and Geophysics: Marine sediments_processes and transport; 4267 Oceanography: General: Paleoceanography; 9609 Information Related to Geologic Time: Mesozoic; KEYWORDS: Cretaceous, oceanic anoxic events, Ocean Drilling Program

Citation: Robinson, S. A., T. Williams, and P. R. Bown (2004), Fluctuations in biosiliceous production and the generation of Early Cretaceous oceanic anoxic events in the Pacific Ocean (Shatsky Rise, Ocean Drilling Program Leg 198), Paleoceanography, 19, PA4024, doi:10.1029/2004PA001010.

\section{Introduction}

[2] Our understanding of mid-Cretaceous (BarremianTuronian) Pacific paleoceanography has been severely hampered by the poor recovery of pelagic sequences due to pervasive chert in sediments of this age. Drilling in the Pacific Ocean and work on accreted terranes in North America [Jenkyns, 1980; Schlanger et al., 1987; Sliter, 1989, 1999; Arthur et al., 1990; Bralower et al., 1993, 2002] has yielded some basic information about Cretaceous paleoceanography and sedimentology, including the occurrence of shales rich in organic carbon at discrete points in time. These horizons of so-called "black shale" occur globally and record "oceanic anoxic events" (OAEs) [Schlanger and Jenkyns, 1976; Jenkyns, 1980; Scholle and Arthur, 1980; Arthur et al., 1990]. There are arguably between five and seven OAEs during the BarremianTuronian interval [Arthur et al., 1990; Bralower et al., 1993; Erbacher et al., 1996; Leckie et al., 2002]. The early Aptian OAE 1a (the "Selli Level" in Italy) and the Cenomanian/Turonian boundary OAE 2 (the "Bonarelli Hori-

Copyright 2004 by the American Geophysical Union. 0883-8305/04/2004PA001010 zon" in Italy) are the most significant and widespread of the mid-Cretaceous black shale events occurring throughout the Atlantic, Tethyan and Pacific regions [e.g., Schlanger et al., 1987; Arthur et al., 1990; Jenkyns, 1999; Bralower et al., 1993, 2002] . The other OAEs are less significant and only minor accumulations of organic carbon occur in the Pacific basin that are synchronous with OAEs defined in the Tethys and Atlantic basins. These more minor occurrences of black shale are rather patchy in distribution, stratigraphically thin, and of limited organic carbon content compared to OAE 1a and OAE 2 (e.g., at Site 465 on Hess Rise, upper Albian organic-carbon-rich sediments are common but are not confined to a narrow interval, unlike the sedimentary records of OAE 1a in the Pacific).

[3] The causality of Cretaceous OAEs is still under debate and it may be that a single, unifying theory cannot explain all the unique phenomena associated with each event [see Jenkyns, 1999, 2003; Leckie et al., 2002]. Biosiliceous sediments are commonly associated with black shale horizons [e.g., Schlanger and Jenkyns, 1976; Jenkyns, 1980, 1999, 2003; Arthur and Premoli Silva, 1982; Coccioni et al., 1987, 1989; Schlanger et al., 1987; Bréhéret, 1988; Sliter, 1989; Arthur et al., 1990; Kuhnt et al., 1990; Weissert and Lini, 1991; Thurow et al., 1992], and are often taken, 


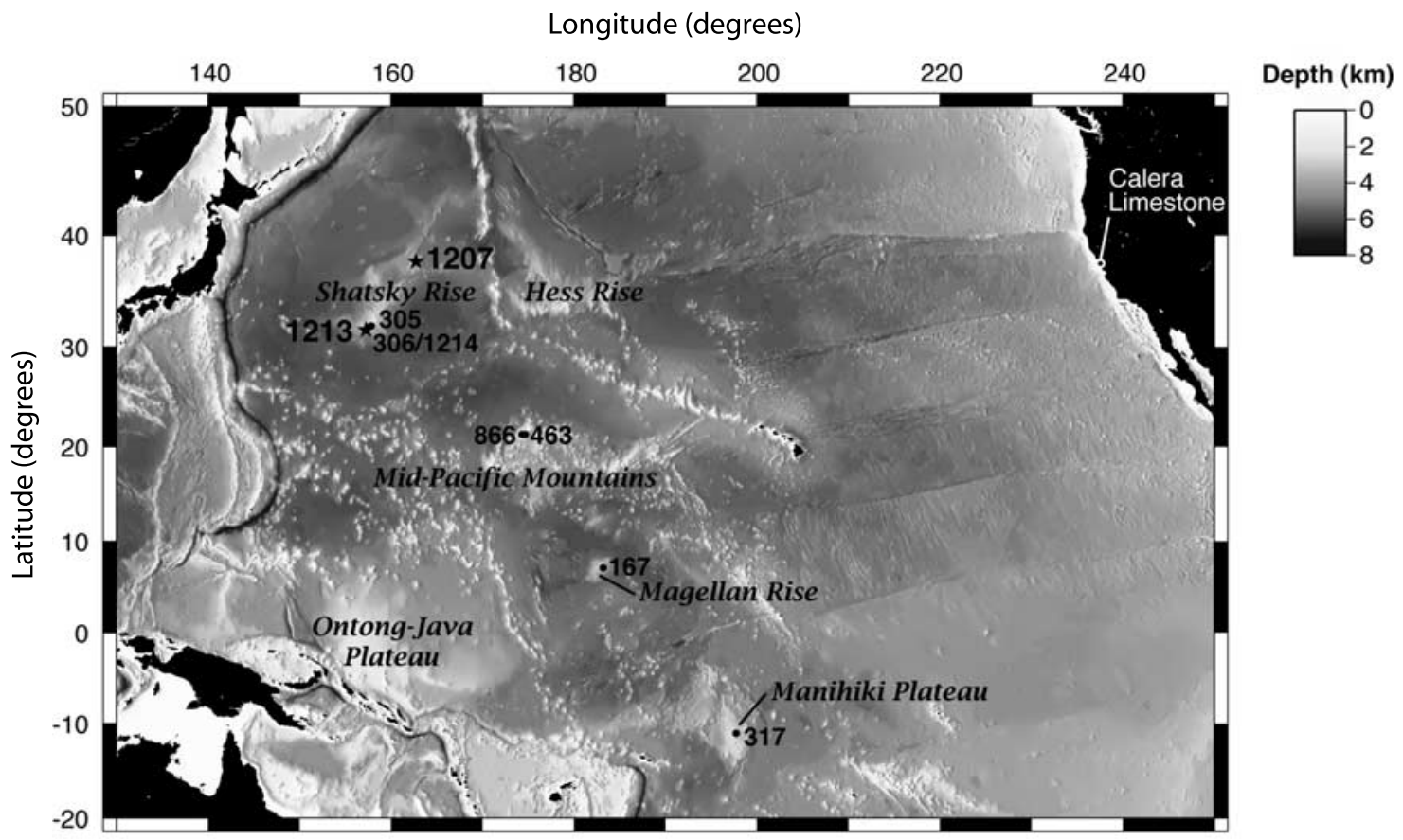

Figure 1. Present-day location of Shatsky Rise and other major submarine volcanic rises and plateaus in the Pacific Ocean. ODP Sites 1207 and 1213, the subject of this paper, are indicated by stars; other important DSDP/ODP sites and the location of the Calera Limestone in California are indicated by circles.

with other proxies, to suggest that high productivity was an important component in the genesis of OAEs. In the restricted basins of the proto-Atlantic and Tethys, phenomena such as water mass stratification, bottom water anoxia, and increased input of terrestrial organic material may also have been significant factors leading to enhanced deposition of organic carbon [e.g., Jenkyns, 1980; Erbacher et al., 2001; Herrle et al., 2003a]. The major periods of carbon burial (OAE 1a and OAE 2) are associated with increasing global warmth and an increase in volcanism [see Jenkyns, 1999, 2003; Jenkyns and Wilson, 1999; Leckie et al., 2002]. A number of studies have suggested that global warming in the Cretaceous drove an increase in nutrient supply through enhanced continental weathering and increased coastal and equatorial upwelling [e.g., Weissert, 1989; Jenkyns, 1999, 2003]. Additionally, the close association in time of large igneous province (LIP) eruption and OAEs suggests that submarine volcanic events may have supplied nutrients (especially iron) to the ocean directly [e.g., Larson and Erba, 1999; Leckie et al., 2002]. Increased nutrient supply (either through upwelling, iron fertilization or continental weathering) would have stimulated plankton productivity causing organic carbon burial rates to rise, potentially leading to the formation of black shales [Jenkyns, 1999, 2003].

[4] Leg 198 of the Ocean Drilling Program to Shatsky Rise drilled Lower Cretaceous sediments at Sites 1207, 1213 and 1214 with very low core recovery (between 0.5 and $55.1 \%$ per core but typically $<20 \%$ ). In many cores, biostratigraphic dating was only possible through the study of chert fragments with chalk coatings and burrow fills.
Nannofossil biostratigraphy suggests that the AptianAlbian at Sites 1207 and 1213 is relatively thick $(\sim 180 \mathrm{~m}$ and $\sim 145 \mathrm{~m}$ respectively), thus making these sites important localities for the study of Pacific paleoceanographic change during the Early Cretaceous. Geophysical logs provide us with stratigraphically continuous records of the downhole physical properties of Cretaceous sediments and interpretation of these allows us to elucidate the sedimentary history and paleoceanography of the Shatsky Rise area, despite the low core recovery.

\section{Material and Methods}

[5] Shatsky Rise is a medium-sized LIP in the northwest Pacific (Figure 1) that formed between the Tithonian (Late Jurassic) and the Valanginian (Early Cretaceous) [e.g., Sager et al., 1988; Nakanishi et al., 1989]. The volcanic activity that led to the formation of Shatsky Rise was intermittent, resulting in three distinct submarine highs, termed the northern, central and southern highs. The volcanic basement is capped by a thick sequence of largely pelagic sediments ranging in age from Early Cretaceous to recent [Ewing et al., 1966; Fischer et al., 1971; Larson et al., 1975; Heath et al., 1985; Bralower et al., 2002]. During Leg 198, Holes 1207B (on the northern high) and 1213B (on the southern high) were logged with the "triple combo" tool string, which measures formation density, porosity, electrical resistivity, natural gamma radiation and hole diameter. In Hole 1207B, the Formationmicroscanner/Sonic (FMS-Sonic) tool string was also used to provide an oriented two-dimensional high-resolution image of resistivity of the Upper Cretaceous and Cenozoic (an 


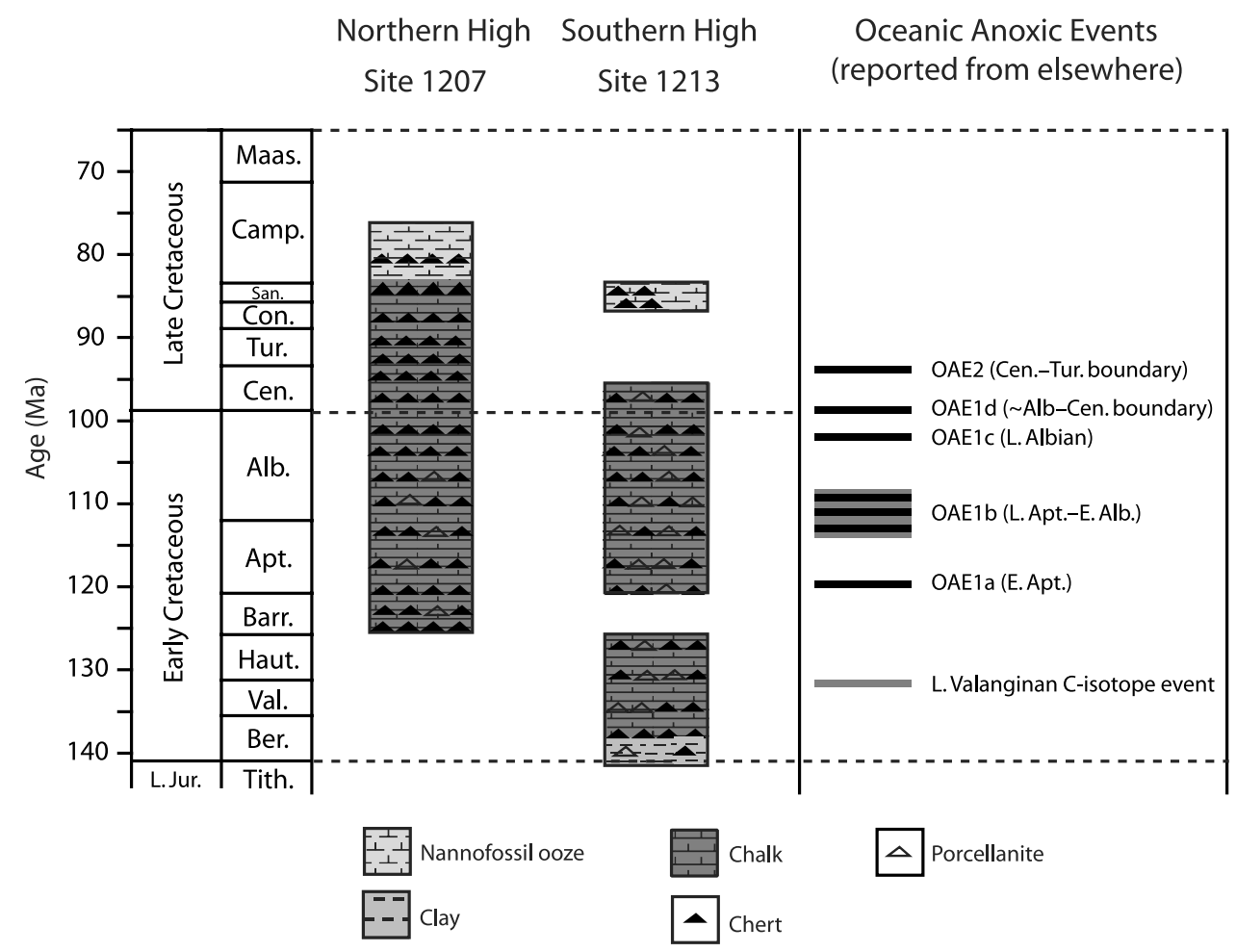

Figure 2. Stratigraphy of Sites 1207 and 1213 based on recovered core, modified from Bralower et al. [2002]. Major paleoceanographic events of the mid-Cretaceous are also shown (ages from Leckie et al. [2002] and Bralower et al. [2002]).

obstruction in the hole prevented the use of this tool string below the upper Albian). Further details of the logging techniques employed aboard Leg 198 can be found in the work of Bralower et al. [2002].

[6] The Cretaceous stratigraphy of Sites 1207 and 1213 is summarized in Figure 2. Re-examination of cores from Sites 1207 and 1213 suggests that the dominant recovered lithologies from the mid-Cretaceous of Shatsky Rise are chert, porcellanite/silicified carbonate (characterized by a dull luster, weak or no reaction with $\mathrm{HCl}$ and less hard/ compact than chert) and chalk (defined as scratching easily with a fingernail), in good agreement with the results of Keene [1975] and Matter et al. [1975] from Sites 305 and 306. The Lower Cretaceous occurrences of "limestone" reported in the work of Bralower et al. [2002] are generally either chalk or porcellanite/silicified carbonate. The terms porcellanite and chert do not reflect the crystallinity or mineralogy of the silica phases [Bralower et al., 2002]. The extremely low recovery percentages suggest that, overall, the dominant in situ lithology is in fact chalk or ooze, as this would be expected to be easily washed away during coring. This supposition is supported by the FMS logs for the upper Albian to Campanian at Site 1207 [Bralower et al., 2002].

[7] The biostratigraphic framework used in this paper is based, almost entirely, on nannofossil datums. Recovery was too poor to construct a complete planktic foraminiferal biostratigraphy, although foraminifera have been used to provide some constraint to interpretations discussed later. The biostratigraphic and chronostratigraphic framework of the mid-Cretaceous used in this study is given in Figure 3 and is the same as that used during Leg 198 (see Bralower et al. [2002] for details). The shipboard nannofossil biostratigraphic zonation [Bralower et al., 2002] of Sites 1207 and 1213 has been slightly reassessed and the revised zonations are used here (P. R. Bown, Early to mid-Cretaceous calcareous nannoplankton from the northwest Pacific Ocean (ODP Leg 198, Shatsky Rise), submitted to Proceedings of the Ocean Drilling Program, Scientific Results, 2004).

\section{Hole 1207B: Logging Results}

[8] A full description of the logging data for Hole 1207B can be found in the work of Bralower et al. [2002]. Figure 4 is a compilation of biostratigraphic and logging data for the interval between 620 and 340 mbsf, dated as late Hauterivian/Barremian to Cenomanian in age. Density and porosity are generally inversely correlated, as would be expected. Porosity and resistivity are also inversely related to one another. The reliability of resistivity, porosity and density measurements is subject to the condition of the hole, especially the diameter. If the diameter is too large porosity will be overestimated, whereas density and resistivity will be underestimated. Potentially this could result in the inverse correlations described above. However, removal of all the data points for which the calliper measurement exceeded 16 inches has no discernable effect on the observed downhole trends.

[9] The shipboard scientific party recognized a total of six logging units in the entire section logged in Hole 1207B 


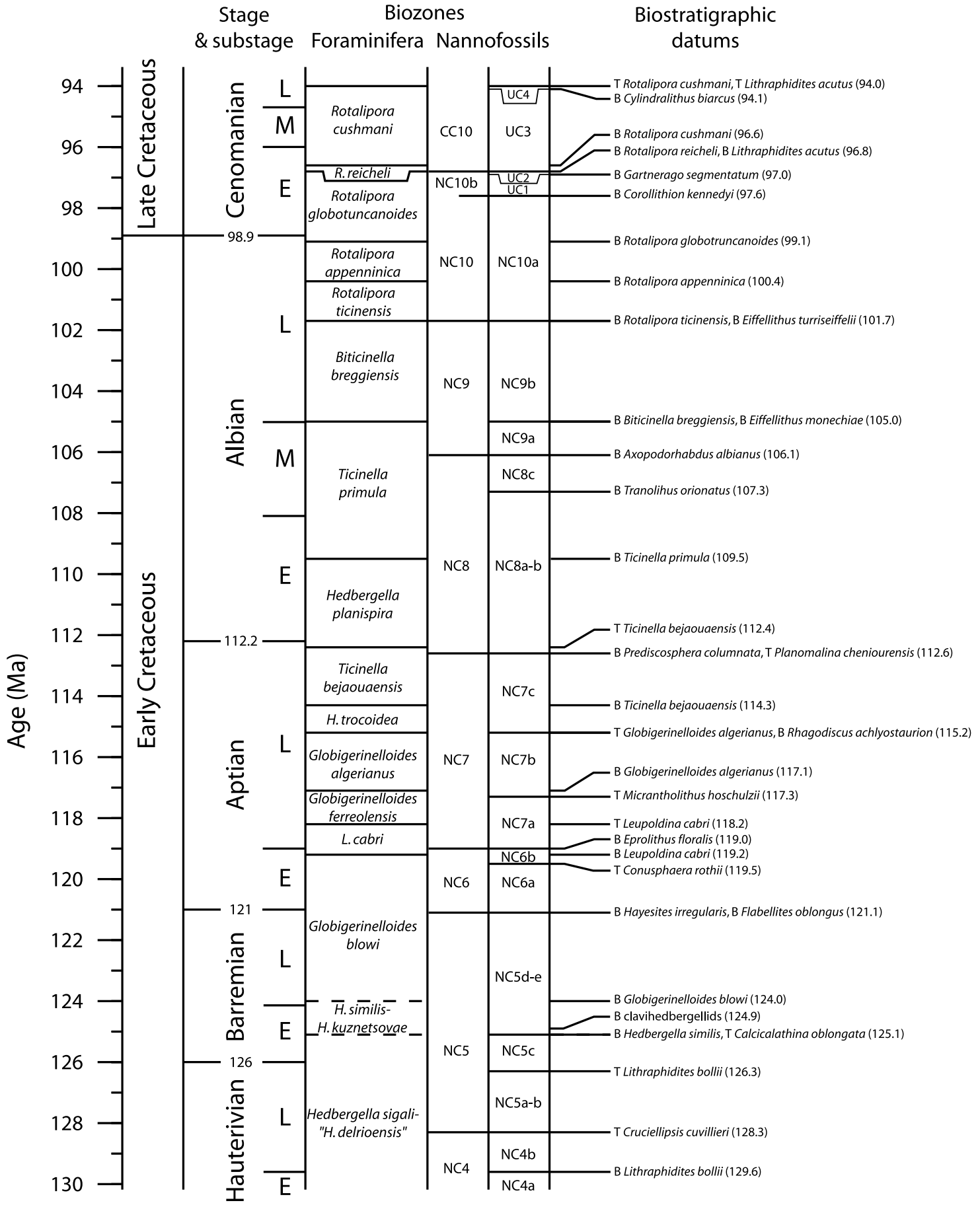

Figure 3. Chronostratigraphy and biostratigraphy of the mid-Cretaceous, after Bralower et al. [2002]. Substage boundaries from Bralower et al. [1995], Channell et al. [1995], Gradstein et al. [1995], and Leckie et al. [2002].

[Bralower et al., 2002]. Units 3 to 6 span the BarremianCenomanian interval [see Bralower et al., 2002]. Units 3 and 5 are less dense, more porous and less resistive than units 4 and 6 . The recovered lithologies from units $3-6$ are summarized in Table 1. Because of the exceedingly poor recovery (Figure 4) there do not appear to be any clear relationships between changes in the physical properties (as recorded by the downhole logs) and recovered lithologies, with the exception of a very distinct peak in gamma ray values and uranium concentration at $566 \mathrm{mbsf}$ that represents organic-carbon-rich shale (up to $35 \mathrm{wt} \%$ total organic carbon (TOC)) in core 198-1207B-44R-1. The age of this bed (early Aptian nannofossil zone NC6) indicates that it is equivalent to the "Selli Level" of Italy and OAE 1a. The recovered thickness of black shale is $\sim 45 \mathrm{~cm}$, but based on the logging data the real thickness of the black shale in situ 


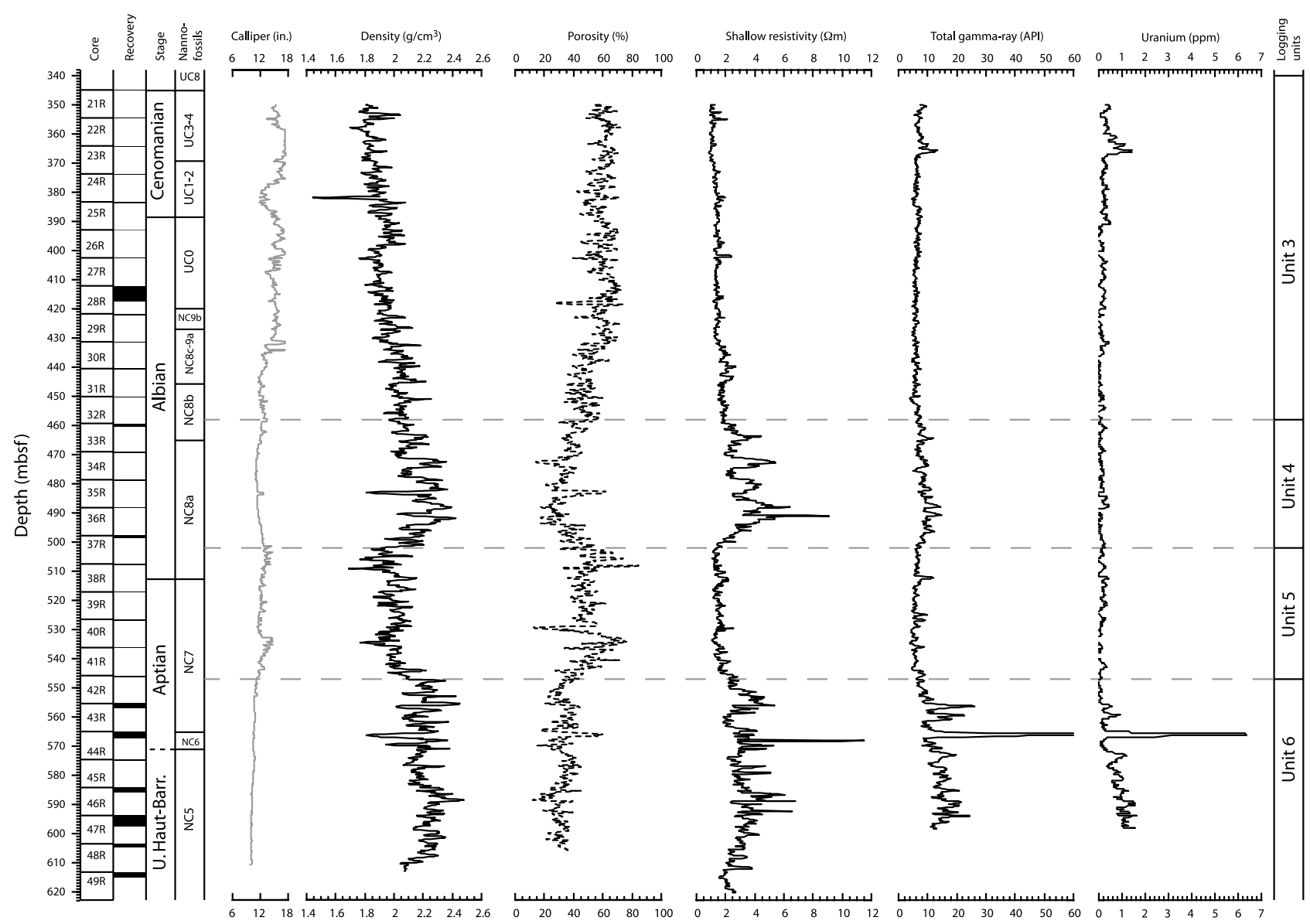

Figure 4. Geophysical logging data and nannofossil biostratigraphy of Hole $1207 \mathrm{~B}$ between 340 and 620 mbsf. In the "recovery" column, black indicates recovered core, and white indicates core gaps.

is $\sim 1.2 \mathrm{~m}$ [Bralower et al., 2002]. Thin beds of radiolarian silt occur at the base and in the upper part of the black shale. Pyritized radiolarians and small nodules of pyrite occur in the beds above and below the black shale. There is also an abundance of radiolarite and silicified limestone fragments stratigraphically close to the black shale.

\section{Hole 1213B: Logging Results}

[10] A full description of the logging data for Hole $1213 \mathrm{~B}$ can be found in the work of Bralower et al.
[2002]. Figure 5 is a compilation of biostratigraphic and logging data for the interval between 270 and $180 \mathrm{mbsf}$, dated as Hauterivian to Albian in age, although the entire Barremian is missing. The shipboard scientific party recognized a total of six logging units in the entire section logged in Hole 1213B [Bralower et al., 2002]. Units 1 to 3 span the Aptian-Albian interval [see Bralower et al., 2002]. Units 1 and 3 are less porous and more resistive than unit 2 . The recovered lithologies from units 1-3 are summarized in Table 2. A large peak in gamma ray values and uranium concentrations occurs in the

Table 1. Summary of Recovered Lithologies From Mid-Cretaceous Logging Units at Site $1207^{\mathrm{a}}$

\begin{tabular}{|c|c|c|c|}
\hline $\begin{array}{l}\text { Logging } \\
\text { Unit }\end{array}$ & $\begin{array}{l}\text { Depth, } \\
\text { mbsf }\end{array}$ & Age & Recovered Lithologies \\
\hline 3 & $340-458$ & m. Alb.-Cen. & $\begin{array}{l}\text { chert (with chalk coatings and porcellaneous } \\
\text { coatings) and minor amounts of calcareous } \\
\text { porcellanite, chalk, some carbonate ooze }\end{array}$ \\
\hline 4 & $458-502$ & e. Alb. & $\begin{array}{l}\text { chert (chalk as burrow fills and coatings) and } \\
\text { some porcellanite }\end{array}$ \\
\hline 5 & $502-547$ & 1. Apt. & $\begin{array}{l}\text { chert, chalk (in core 1207B-40R) and some } \\
\text { calcareous porcellanite, silicified chalk }\end{array}$ \\
\hline 6 & $547-622$ & 1. Bar--e. Apt. & $\begin{array}{l}\text { chert, chalk, porcellanite, organic-rich claystone, } \\
\text { radiolarites }\end{array}$ \\
\hline
\end{tabular}

${ }^{a}$ Here Cen., Cenomanian; Alb., Albian; Apt., Aptian; Bar., Barremian; e., early; m., middle; 1., late. 


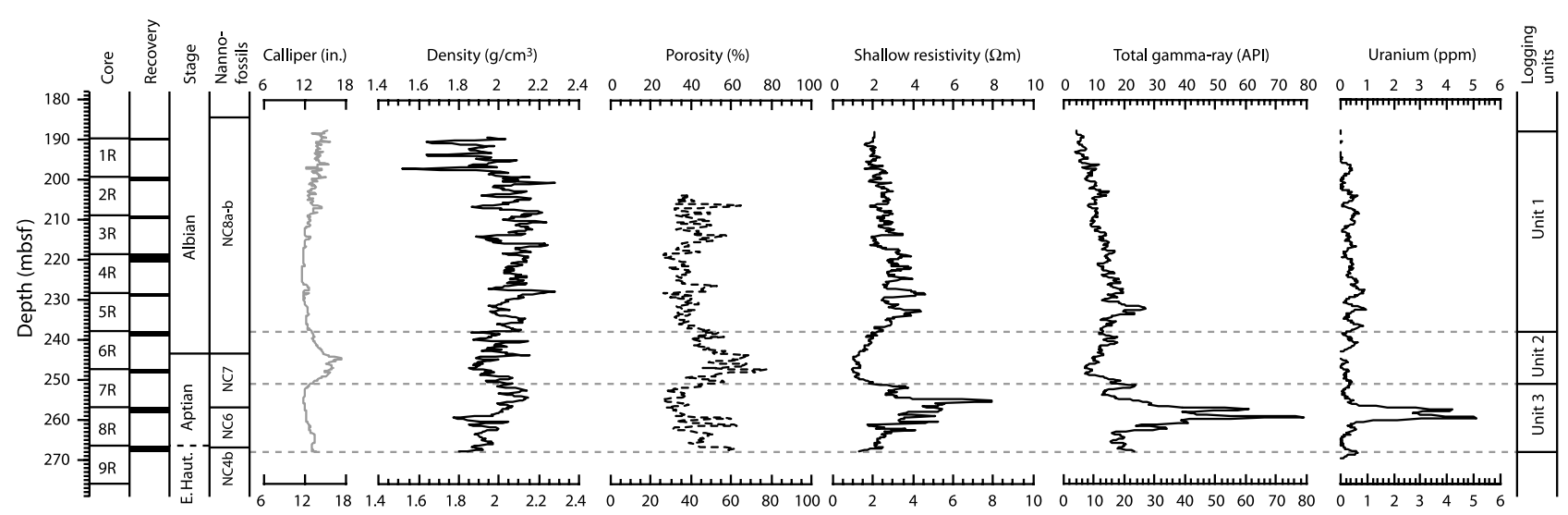

Figure 5. Geophysical logging data and nannofossil biostratigraphy of Hole $1213 \mathrm{~B}$ between 180 and 270 mbsf. In the "recovery" column, black indicates recovered core, and white indicates core gaps.

lower Aptian (nannofossil zone NC6) that is caused by the presence of organic-carbon-rich clayey porcellanite (TOC <25.2 wt \%; Bralower et al. [2002]) recovered in core 198-1213B-8R.

\section{Correlation of Holes 1207B and 1213B}

[11] Similar stratigraphic patterns exist in the resistivity and porosity data from Holes $1207 \mathrm{~B}$ and 1213B. The early to early-late Aptian (nannofossil zones NC6 and part of NC7) is characterized by maxima in resistivity in both holes (Figure 6). Through most of the upper part of zone $\mathrm{NC7}$, resistivity values are very low, exhibiting none of the major fluctuations seen in zone NC6. Just above the Aptian/Albian boundary, resistivity values show a gradual increase at both sites, reaching a peak in subzone NC8a, followed by an overall decline in resistivity values through the remainder of subzones NC8a and NC8b. The early Albian "resistivity high" is composed of 5 or 6 individual peaks in resistivity at both sites. It is not possible to correlate individual peaks in the resistivity data with absolute certainty, as there are undoubtedly some "local effects" (e.g., the resistivity peaks at $\sim 570$ mbsf in Hole 1207B and at $\sim 254$ mbsf in Hole 1213B occur, respectively, below and above the black shale). However, the large-scale trends in resistivity are broadly synchronous. Given that these sites are over $900 \mathrm{~km}$ apart, it seems unlikely that the pattern in the resistivity data is the result of local diagenetic processes; thus, there must be a fundamental primary control on the physical properties of the sediments common to both sites.

\section{Physical Properties of Pelagic Sediments 6.1. Strategy}

[12] In order to interpret the Aptian-Albian sedimentary history of Shatsky Rise from the fragmentary lithological record and the downhole logs, it is necessary to consider the physical properties of the recovered lithologies. We have conducted a thorough review of the DSDP and ODP literature to determine the physical characteristics of Lower Cretaceous biosiliceous and pelagic carbonate sediments in the Pacific Ocean.

\subsection{Resistivity}

[13] Resistivity measurements are difficult to make on core samples because of (1) changes in pore water content and chemistry after core recovery; and (2) lack of suitable equipment for measurements. Some workers have managed to produce resistivity images (similar to downhole FMS $\operatorname{logs}$ ) on complete, soft sediment sections [e.g., Jackson et al., 1997, 1998] but data on discrete core samples do not exist. Electricity is conducted through a formation only if conductive water is present; consequently the resistivity of the pore water, the amount of water present, and the pore structure geometry will contribute to the measured resistivity values [Schlumberger Educational Services, 1989]. A highly resistive formation therefore has low porosity and low pore

Table 2. Summary of Recovered Lithologies From Mid-Cretaceous Logging Units at Site $1213^{\mathrm{a}}$

\begin{tabular}{|c|c|c|c|}
\hline $\begin{array}{l}\text { Logging } \\
\text { Unit }\end{array}$ & $\begin{array}{l}\text { Depth, } \\
\text { mbsf }\end{array}$ & Age & Recovered Lithologies \\
\hline 1 & $188-238$ & e. Alb. - m. Alb. & chert, radiolarite, calcareous porcellanite, chalk \\
\hline 2 & $238-251$ & 1. Apt. & $\begin{array}{l}\text { chert and porcellanite (with chalk coatings), } \\
\text { radiolarites at base of unit }\end{array}$ \\
\hline 3 & $251-268$ & e. Apt. & $\begin{array}{l}\text { radiolarian-rich porcellanite, organic-rich clayey } \\
\text { porcellanite, chert and minor amounts of altered } \\
\text { tuff and silicified carbonate }\end{array}$ \\
\hline
\end{tabular}

${ }^{\mathrm{a}}$ Here Alb., Albian; Apt., Aptian; e., early; m., middle; 1., late. 


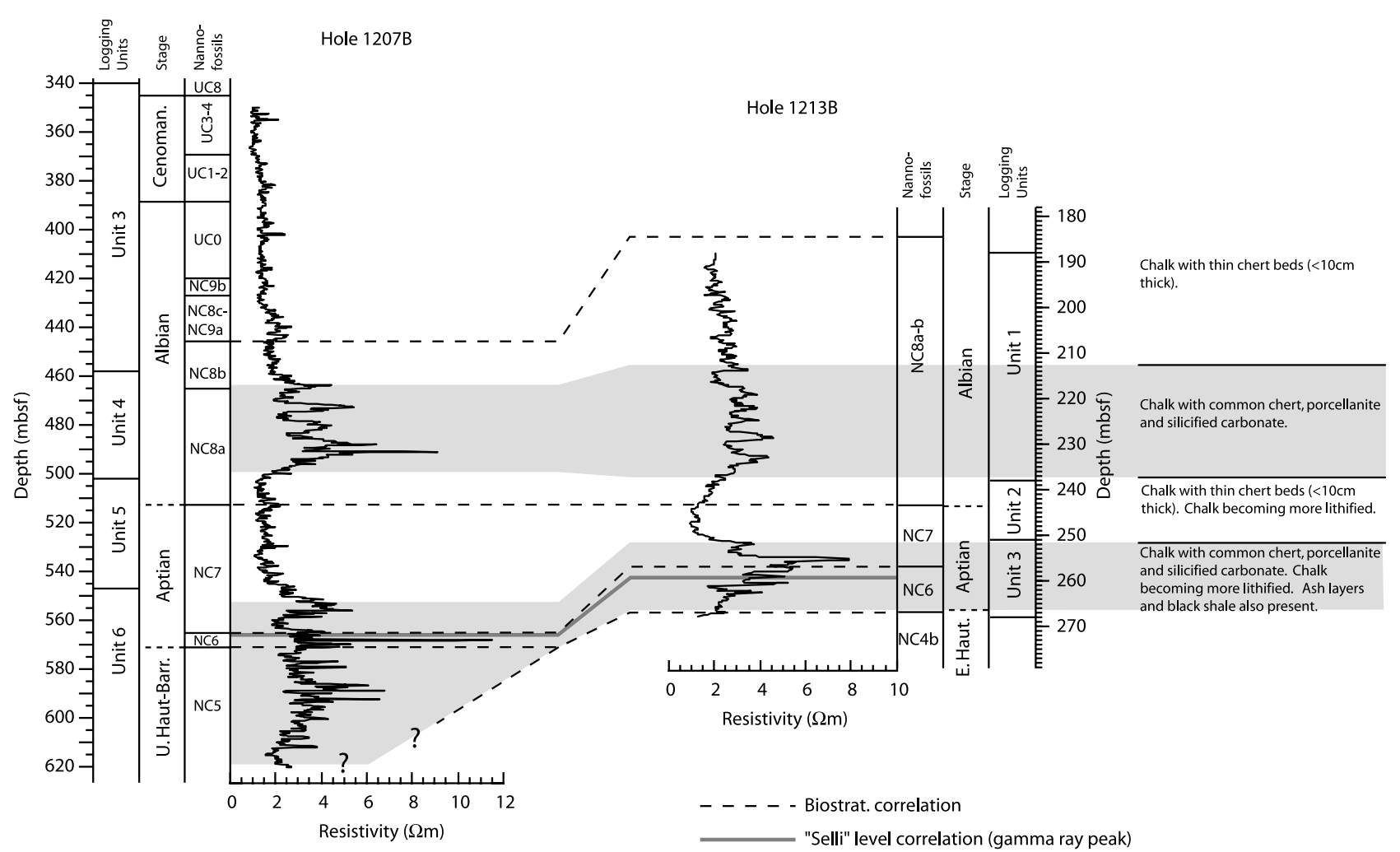

Figure 6. Summary of sedimentological interpretations and correlation between Sites 1207 and 1213 . Correlation is based upon nannofossil biostratigraphy, geophysical, and lithological data.

water content. Given a constant seawater origin for the pore fluids on Shatsky Rise, it seems likely that the dominant control on resistivity is the amount of porosity. FMS images from the Upper Cretaceous of Hole 1207B show thin, highly resistive units between very conductive layers that have been interpreted as thin chert horizons interbedded with soft carbonate ooze and chalk [Bralower et al., 2002]. The FMS tool was not used in the Aptian-Albian sections from either Hole 1207B or Hole 1213B but the interpretations of the Upper Cretaceous FMS logs can be applied to the standard resistivity measurements made by the Dual Induction Tool in the Lower Cretaceous.

\subsection{Porosity}

[14] In the past, porosity has been calculated from both gamma ray attenuation (GRA) density and wet bulk density measurements and, as a result, the quality of a reported porosity value relies on the accuracy of the density measurement (see below). Porosity calculations were not made on the Lower Cretaceous sediments from Leg 198 because of the poor recovery. In Table 3 we present typical porosity values for Lower Cretaceous pelagic lithologies based upon a review of data from DSDP and ODP legs in the Pacific Ocean. It is probable that the lowest porosity values recorded by the $\operatorname{logs}$ are horizons rich in chert; higher porosity values correspond to horizons rich in chalk.

\subsection{Density}

[15] The bulk density of mid-Cretaceous sediments from Site 1207 was measured using a gamma ray attenuation (GRA) bulk density device on a multisensor track (MST). The reliability of the measurements is questionable because some values are negative and obviously erroneous. In RCB (rotary core barrel) cores the quality of the GRA measurements is low because sediment rarely completely fills the core

Table 3. Typical Physical Property Values and Characteristics of Lower Cretaceous Pelagic Sediments From the Pacific Ocean Used to Interpret Downhole Geophysical Logs From Shatsky Rise ${ }^{\text {a }}$

\begin{tabular}{lcccc}
\hline \multicolumn{1}{c}{ Lithology } & Density, $\mathrm{g} / \mathrm{cm}^{3}$ & Porosity, $\%$ & Resistivity & Gamma Ray \\
\hline Chalk & $\sim 1.6-2.0$ & $\sim 50-60$ & relatively low & low \\
Chert & $\sim 2.6$ & $\sim 3-5$ & higher than chalk & low \\
Porcellanite & $\sim 2.2$ & $\sim 15$ & higher than chalk & low \\
$\begin{array}{l}\text { Claystone/black } \\
\text { shale }\end{array}$ & $\sim 1.6-2.0$ & $\sim 40-60$ & depends on degree & high (clays and \\
P & & (apparent in logs) & of cementation & organic matter) \\
\hline
\end{tabular}

${ }^{a}$ Data compiled from DSDP Legs 17, 30, 32, 33, 62 and ODP Legs 130, 192, 198 [Winterer et al., 1973; Schlanger and Douglas, 1974; Andrews et al., 1975; Keene, 1975; Larson et al., 1975; van der Lingen and Packham, 1975; Schlanger et al., 1976; Thiede et al., 1981; Kroenke et al., 1991; Mahoney et al., 2001; Bralower et al., 2002]. 
Table 4. Average Physical Property Values for Logging Units 3-6 From Hole $1207 \mathrm{~B}^{\mathrm{a}}$

\begin{tabular}{lccccc}
\hline $\begin{array}{l}\text { Logging } \\
\text { Unit }\end{array}$ & Depth, mbsf & Age & $\begin{array}{c}\text { Density, } \\
\text { g/cm }\end{array}$ & Porosity, \% & $\begin{array}{c}\text { Resistivity, } \\
\Omega \mathrm{m}\end{array}$ \\
\hline 3 (part of) & $340-458$ & m. Alb.-Cen. & 1.9 & 56.9 & 1.5 \\
4 & $458-502$ & e. Alb. & 2.2 & 35.1 & 3.2 \\
5 & $502-547$ & 1. Apt. & 2.0 & 49.6 & 1.6 \\
6 & $547-622$ & 1. Bar.-e. Apt. & 2.2 & 32.4 & 3.1 \\
\hline
\end{tabular}

${ }^{\mathrm{a}}$ Here Cen., Cenomanian; Alb., Albian; Apt., Aptian; Bar., Barremian; e., early; m., middle; 1., late.

barrel. Additionally the GRA calibration is optimized for mixed-lithology sediments and consequently tends to overestimate density in carbonate-rich sediments. Discrete wet bulk density measurements of Lower Cretaceous sediments were not made on Leg 198 due to the poor recovery. A review of density data from DSDP and ODP legs in the Pacific Ocean (Table 3) demonstrates that the density of chert and porcellanite is relatively consistent from site to site. In contrast, the density of chalk can vary considerably as a result of different burial and diagenetic histories and possibly different primary compositions (i.e., proportion of nannofossils versus microfossils; see Schlanger and Douglas [1974]).

\section{5. $P$ Wave Velocity}

[16] $P$ wave velocities increase as density, compaction and cementation increase [e.g., Schlanger and Douglas, 1974]. Thus, $P$ wave data can provide an indication of the relative physical properties of different lithologies. The data collected on Leg 198 confirm that cherts have higher $P$ wave velocities (e.g., at Site $1213 \sim 4.7 \mathrm{~km} / \mathrm{s}$ ) than carbonates (e.g., $\sim 1.9 \mathrm{~km} / \mathrm{s}$ at Site 1213). Porcellanites and radiolarites from Site 1213 have intermediate values of $\sim 2.7$ and $\sim 3.1 \mathrm{~km} / \mathrm{s}$, respectively. Keene [1975] reports similar ranges for $P$ wave velocities for cherts and porcellanites recovered during DSDP Leg 32 to those measured during Leg 198: specifically 2.2 to $3 \mathrm{~km} / \mathrm{s}$ for porcellanite and 3.9 to $5.2 \mathrm{~km} / \mathrm{s}$ for chert.

\subsection{Summary}

[17] The major lithologies have predictable relative physical property values. Chalk will have the highest porosity, lowest resistivity and lowest density; conversely, chert will have the lowest porosity, highest resistivity and highest density. Porcellanite will lie in between these two endmembers. Obviously, varying lithification and abundance of silica and carbonate within chalk, porcellanite and chert will effect the physical properties and as such it is entirely reasonable to expect overlap between the range of values measured in each lithology. Thus, in the Lower Cretaceous pelagic sediments on Shatsky Rise, higher density and resistivity values indicate a higher silica content in the sediment.

\section{Mid-Cretaceous Sedimentary History of Shatsky Rise}

[18] The logging measurements have a stratigraphic resolution of $\sim 30 \mathrm{~cm}$ and as such each data point represents an average value for this interval of stratigraphy. Therefore it is unlikely that the physical values recorded by the logs represent the extremes of the discrete measurements made on actual rock samples. For example, a series of closely spaced, 10-cm-thick chert layers might not be resolved by the logs presented here. Site 1207 displays clear changes in porosity, density and resistivity through the Aptian-Albian interval. Comparison between the expected values for each major lithology (Table 3) and the average values for each unit at Site 1207 (Table 4) allows us to propose the gross lithological characteristics of each logging unit. We consider the high-resistivity, high-density, low-porosity units of the Barremian-Aptian and lower Albian (units 6 and 4) to be intervals with a greater abundance of cemented, indurated, siliceous sediments (Figure 6). In contrast, the low-resistivity, lower-density, higher-porosity units of the upper Aptian and the middle to upper Albian (units 5 and 3) probably represent less cemented, softer sediments, which have less silica.

[19] On the basis of the correlations discussed above, and the patterns of resistivity and porosity, we propose that the general sedimentary history of Site 1213 was similar to that of Site 1207 (see summary in Figure 6). The low correlation between density and resistivity at Site 1213 could be a function of poor hole conditions, a problem with the density tool or averaging of alternating thin beds of chert and chalk. Our interpretation of the sedimentary history for Sites 1207 and 1213 is supported by Keene [1975] and Matter et al. [1975], who reported that, at Sites 305 and 306 on Shatsky Rise, the abundance of recovered porcellanite and silicified limestone was highest in the upper Barremian-lower Albian. Unfortunately, these data from Sites 305 and 306 have insufficient stratigraphic resolution to determine whether the abundance of porcellanite fluctuated in the mid to upper Aptian, as proposed here.

[20] Cretaceous siliceous sediments on Shatsky Rise appear to be almost entirely biogenic [Keene, 1975; Bralower et al., 2002]. Keene [1975] notes that undissolved radiolarians are recognizable in some of the cherts and porcellanites. Radiolarites and radiolarian cherts dominate pelagic siliceous sediments for much of the Mesozoic [e.g., Jenkyns and Winterer, 1982; Baumgartner, 1987; Maliva et al., 1989; Racki and Cordey, 2000]. The paucity of diatoms in the Lower Cretaceous siliceous sediments of Shatsky Rise indicates that either they were not a significant part of the plankton or they have been removed by dissolution [Jenkyns and Winterer, 1982; Burkle, 1998; Gersonde and Harwood, 1990; Harwood and Gersonde, 1990].

[21] While there may have been some localized mobilization of silica (on a decimeter scale), it is unlikely that a significant amount will have been sufficiently mobilized vertically (on a meter scale) to cause the observed patterns in resistivity at both sites. This suggests that the high resistivity units represent intervals with an increased biosiliceous component. This could be interpreted as an increase in the biosiliceous flux to the seafloor or a decrease in carbonate content (possibly caused by a shallowing of the CCD), hence lessening the effects of carbonate dilution, or possibly some combination of both processes. A change in the CCD alone cannot have had a significant effect on the 


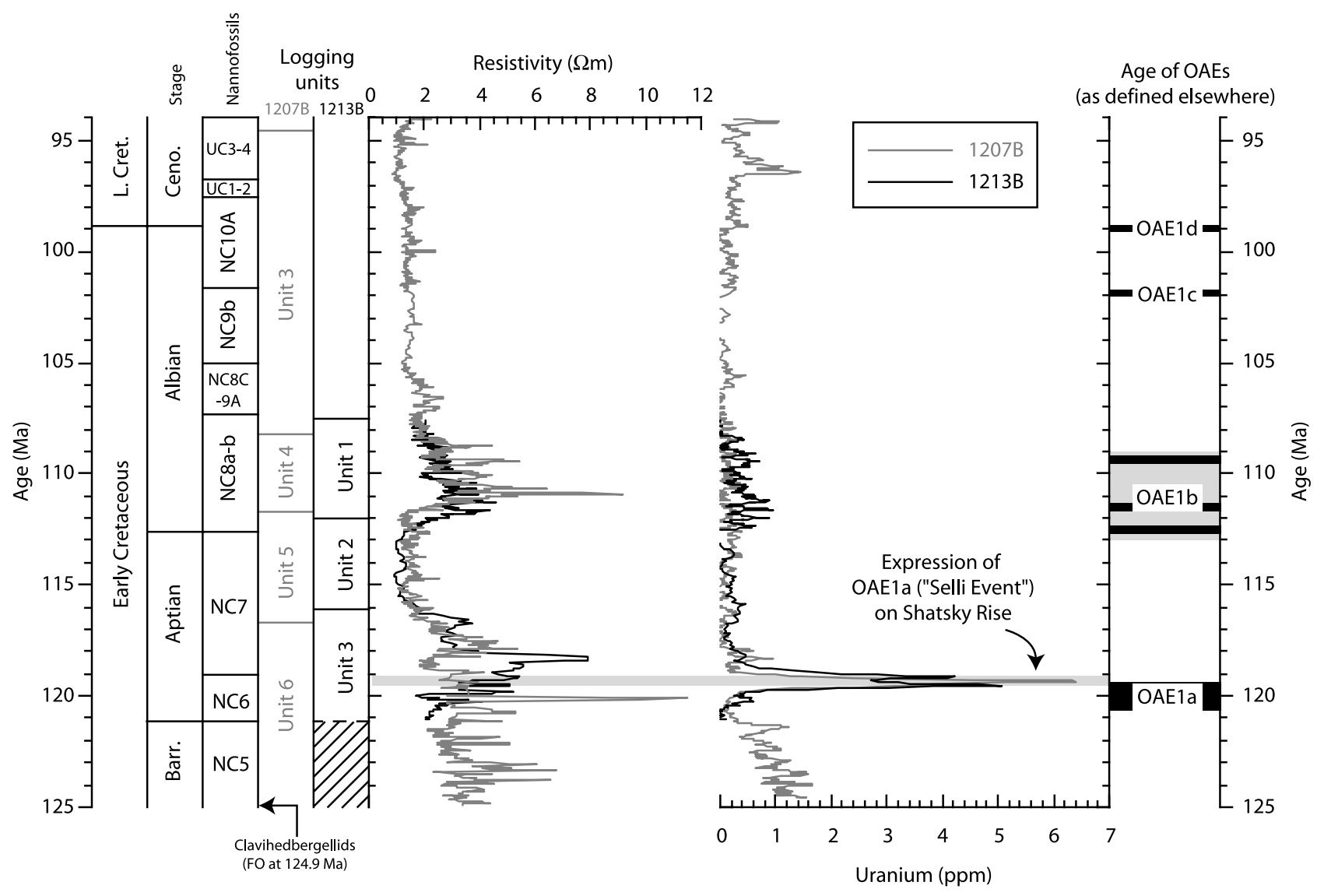

Figure 7. Mid-Cretaceous logging data from Sites 1207 and 1213 plotted against age. Also shown are the ages of OAEs, as defined elsewhere [after Leckie et al., 2002]. Age model used is based upon nannofossil age datums (Figure 3), with the exception of the first occurrence of Clavihedbergellids in Hole 1207B. Ceno., Cenomanian; Barr., Barremian.

physical properties recorded by the wire line logs as chalk and nannofossils are still well-preserved throughout most of the interval of interest at both sites.

[22] The logging units and the observed trends are broadly comparable in age at both sites (Figure 7) and the "resistivity highs" are coincident in time with OAE 1a (as defined at Shatsky Rise and elsewhere) and OAE $1 \mathrm{~b}$ (as defined in the Tethyan and Atlantic region). The large uranium peak represents the black shale resulting from OAE 1a, although it appears to be slightly younger (by $<1 \mathrm{Myr}$ ) than the generally accepted age of OAE 1a elsewhere [see Leckie et al., 2002]. There appears to be a minor enrichment of uranium during the early Albian at Site 1213, which may be associated with slightly elevated organic carbon burial rates. However, there is no evidence, either in core or log data, for a major accumulation of organic carbon during the early Albian on Shatsky Rise.

[23] The calculated sedimentation rates for individual logging units (Table 5) appear to be highest during the early Albian (unit 4 in Hole 1207B; unit 1 in Hole 1213B). This is consistent with an increased flux of biosiliceous material to the seafloor. Taken at face value, sedimentation rates during the Barremian-Aptian "resistivity high" (unit 6 in Hole 1207B; unit 3 in Hole 1213B) do not appear to be much different from those in the late Aptian "resistivity low." However, the vertical limits of each logging unit are not always at, or close to, the same level as a biostratigraphic datum and, in these cases, average sedimentation rates of biozones are not the same as logging unit sedimentation rates. Thus it is impossible to detect sedimentation rate changes between the logging units in the Barremian-Aptian. Furthermore, because of the low recovery, the age model contains errors associated with the positioning of zonal boundaries. An alternative approach is to consider the sedimentation rate of $\mathrm{NC6}$ as being representative of the entire resistivity anomaly and to then extrapolate this sedimentation rate for the total thickness of the resistivity anomaly. At Site 1213, NC6 has a sedimentation rate of $4.7 \mathrm{~m} / \mathrm{Myr}$. When this is extrapolated to the entirety of unit 3, the sedimentation rate of unit 2 becomes $1.5 \mathrm{~m} / \mathrm{Myr}$. At Site 1207 the extrapolation of the NC6 sedimentation rate $(2.8 \mathrm{~m} / \mathrm{Myr})$ results in an unreasonable age estimate for the top of the "resistivity high" and as such cannot be considered representative of the whole of unit 6 . The low sedimentation rate raises the question of whether NC6 is complete at Site 1207. The sedimentation rate for the Barremian at Site 1207 is approximately $7.9 \mathrm{~m} / \mathrm{Myr}$ (FO clavihedbergellids to base of NC6). Extrapolation of this rate above NC6 for the remainder of unit 6 has a negligible effect on the sedimentation rates given in Table 5. However, 
Table 5. Average Sedimentation Rates Based Upon the Assumption of Constant Sedimentation Rate Between Biostratigraphic Datums ${ }^{\mathrm{a}}$

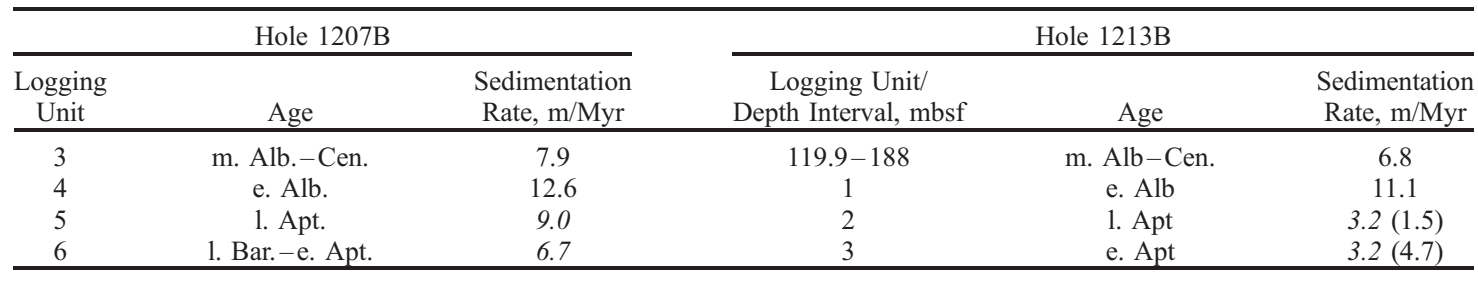

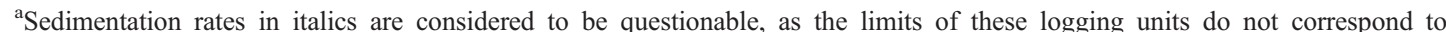
biostratigraphic datums. In Hole 1213B, alternative sedimentation rates are given in parentheses based upon the extrapolation of the sedimentation rate of zone NC6 to the entirety of logging unit 3. See text for further discussion. The depth interval of 119.9 to 188 mbsf in Hole 1213B represents the sediments overlying unit 1 up to the base of nannofossil subzone NC10b (present in Hole $1213 \mathrm{~A}$ ).

the sedimentation rate for the Barremian should be considered as a minimum as the first occurrence of the clavihedbergellids could be deeper in the hole than reported by Bralower et al. [2002].

\section{Discussion and Implications}

\subsection{Possible Mechanisms for Increasing the Flux of Biosiliceous Material to the Seafloor}

[24] Consideration of the geophysical logging, sediment physical property and sedimentation rate data strongly suggests that there was an increase in biosiliceous sedimentation during two discrete intervals in the BarremianAptian and early Albian. Opal production in the modern ocean is highest in the Southern Ocean, the North Atlantic and the equatorial and North Pacific [e.g., Lisitzin, 1972; Broecker and Peng, 1982; Leinen et al., 1986]. Moderate productivity rates occur in the Pacific equatorial divergence zone about 5 degrees either side of the equator [e.g., Barron and Moore, 1994]. Predicted upwelling patterns for the Cretaceous [e.g., Barron, 1985] suggest that the Pacific equatorial divergence zone had a similar gross morphology to the modern Pacific (i.e., parallel to the equator).

[25] Radiolarians are often taken to be indicators of high primary productivity, because of the nutrient limitation of their food sources (e.g., dinoflagellates and bacteria) and symbionts [Anderson, 1983; Baumgartner, 1987; De Wever and Baudin, 1996; Racki and Cordey, 2000] and the common association of radiolarians with other productivity indicators (diatoms, planktonic foraminiferal indices, organic carbon, pyrite, etc.) [e.g., Jenkyns, 1980, 1999; Leckie, 1984; De Wever, 1994; De Wever and Baudin, 1996; Wang and Abelmann, 2002]. The close match between the sedimentation pattern of modern radiolarians and areas of high fertility and high nutrient concentrations [e.g., Renz, 1976] led Baumgartner [1987] to suggest that any sufficiently fertile and nutrient-rich area may have resulted in radiolarite formation in the geologic past.

[26] Siliceous sediments occur through much of the Cretaceous on Shatsky Rise suggesting it was located in, or close to, the equatorial divergence zone for $>40$ million years. The abundance of biosiliceous material (almost entirely radiolarian in origin) in pelagic Mesozoic sediments has led some workers to suggest that the equatorial divergence zone was greatly expanded at this time [Baumgartner,
1987; Bralower et al., 2002], whereas others have maintained that the equatorial zone was as narrow as it is in the modern Pacific Ocean [Erba, 1992]. Ogg et al. [1992] have postulated the existence of an equatorial Pacific "silica bulge" during the Jurassic-Early Cretaceous, which they suggested could be used to indicate the proximity of sites to the equator. The two maxima in biosiliceous supply could not have resulted from repeated crossing through the peak zone of equatorial divergence because Shatsky Rise appears to have remained at a near-constant paleolatitude, (maximum of 1 to $3^{\circ}$ of northward motion) during the Aptian to late Albian and did not pass south of the equatorial divergence zone (Figure 8) [Larson et al., 1992; Wilson et al., 1998; Sager and Koppers, 2000; Bralower et al., 2002; W. Sager, personal communication, 2003]. Additionally, the changes in the physical properties of the sediments are approximately synchronous (to within $1 \mathrm{Myr}$ ) at Sites 1207 and 1213 (Figure 7 ). As these sites are $\sim 900 \mathrm{~km}\left(\sim 6^{\circ}\right.$ of latitude) apart this observation is more consistent with temporal variations in productivity rather than repeated crossings of the equatorial divergence.

[27] As previously discussed there is evidence for increased sedimentation rates during the early Aptian (at Site 1213) and the early Albian (at both Sites 1207 and 1213), consistent with increased productivity during the "resistivity highs." Paytan [2003] and A. Paytan (personal communication, 2003) have shown that at Site 305 on Shatsky Rise there were peaks in biogenic barite accumulation rates, and hence productivity, during the early Aptian and early Albian, and low accumulation rates of barite in the period between these events.

[28] These proposed increases in equatorial biosiliceous productivity must be considered in the context of the Cretaceous silica cycle. In the modern biogeochemical cycle, silica has a geologically short $\left(<10^{5} \mathrm{yr}\right)$ residence time in the oceans and therefore any sustained period of silica burial would result in the oceans being entirely stripped of silica [Miskell et al., 1985; Tréguer et al., 1995; Racki and Cordey, 2000]. However, the silica cycle in the geological past may have been fundamentally different to that of the present because the major expansion of the diatoms in the post-Eocene allowed the highly efficient removal of silica from the ocean, which possibly also drove Cenozoic radiolarian evolutionary trends [Harper and Knoll, 1975; Maliva et al., 1989; Racki and Cordey, 


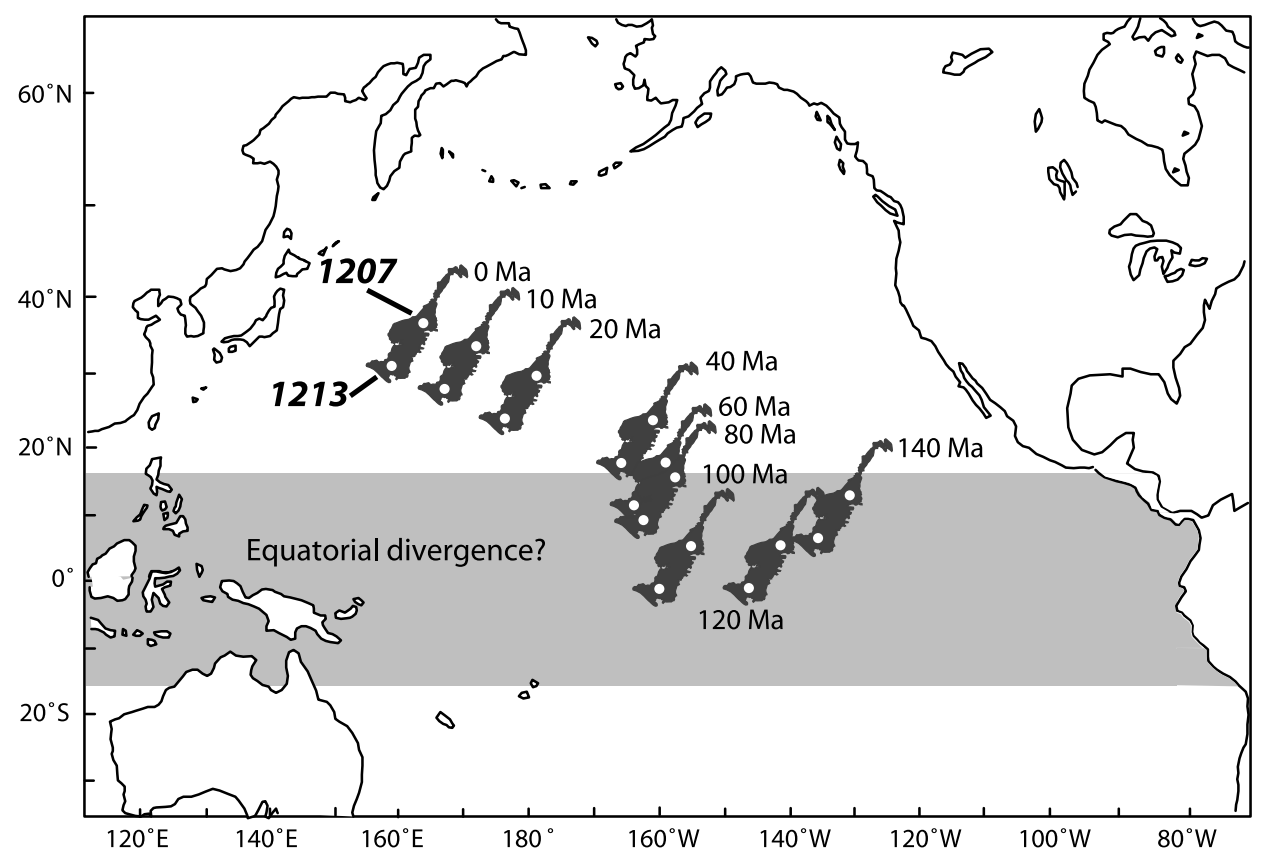

Figure 8. Path of Shatsky Rise across the Pacific Ocean after Bralower et al. [2002].

2000]. Racki and Cordey [2000] suggest that a uniformitarian approach to the biogeochemical silica cycle is invalid in pre-Neogene sediments, because during greenhouse periods the ocean may have been Si-saturated and radiolarian productivity was probably limited by iron and nitrate availability for radiolarian food sources and symbionts [e.g., Baumgartner, 1987]. According to Racki and Cordey [2000, pp. 84-85] the role of volcanism and tectonic controls on radiolarite deposition in the pre-Neogene oceans may also have been important and have been "...overlooked issue $[\mathrm{s}]$ in the preservation versus production controversy, supplementing wind-driven upwelling during puzzling anoxic ocean events corresponding to a basin-wide plankton bloom..." Volcanism supplies biolimiting nutrients and silica to the ocean through increased weathering, dust flux and hydrothermal alteration of basalt (e.g., Racki and Cordey [2000] and discussed in more detail below), thereby stimulating primary productivity. Furthermore, volcanism can effect the preservation of silica, although the degree of importance of this is debatable [see Racki and Cordey, 2000].

\subsection{Aptian-Albian Sedimentation at Other Pacific Ocean Sites}

[29] The record of Aptian-Albian sedimentation in the Pacific Ocean is limited to a few DSDP and ODP sites and to terranes outcropping in California [Jenkyns, 1980; Sliter, 1989; Arthur et al., 1990; Bralower et al., 1993]. Of the DSDP and ODP sites drilled in the Pacific prior to Leg 198, Sites $167,305,317,463$ and 866 are particularly instructive, providing black shale records of OAE 1a that can be compared with those recovered during Leg 198. Table 6 shows the major lithological characteristics and sedimentation rate data for each of these sites, and for the Calera
Limestone of California. Clearly similarities exist between the sedimentary history of Shatsky Rise and other locations in the Pacific basin. For example, average sedimentation rates are similar at most localities, although at Site 463 the early Aptian appears to have been characterized by exceptionally high rates, possibly due to downslope sediment transport. Unfortunately, variation in the biostratigraphic schemes used and poor recovery prevent a direct comparison between sites of sedimentation rates at the zonal level. With the exception of Site 317, all the sites discussed above were within $20-25^{\circ}$ of the equator during the early Aptian. The similarity of the sedimentation rates in the equatorial region (especially at the more pelagic sites, 167, 1207, 1213 and the Calera Limestone) supports the idea of an expanded equatorial divergence zone at this time (possibly $<20^{\circ} \mathrm{N}$ to $<20^{\circ} \mathrm{S}$ ). The lack of pelagic sites further away from the equator prevents further testing of this idea. At Site 463 there appears to be an abundance of biosiliceous sedimentation in the Barremian-Albian, similar to that proposed for Shatsky Rise by Matter et al. [1975], but it is impossible to determine shorter duration fluctuations in biosiliceous content.

[30] OAE 1a seems to be expressed at every locality that has a complete Aptian section, irrespective of facies type, paleowater depth or paleolatitude. Detailed organic geochemical analyses of organic matter associated with OAE 1a are somewhat sparse, particularly for the sites drilled during the early years of DSDP (Sites 167 and 305). Lower Aptian organic-carbon-rich sediments recovered at Sites 463 and 866 have some intervals that are characterized by high HI and low OI indices [Dean et al., 1981; Mélières et al., 1981; Baudin et al., 1995] indicating an algal/bacterial origin (type 1) for the organic matter, consistent with data from Shatsky Rise and possibly suggestive of some uniformity of 
Table 6. Summary of the Aptian-Albian Sedimentary History of DSDP Sites 167, 305, 306, 317, 463, ODP Site 866, and the Calera Limestone in California

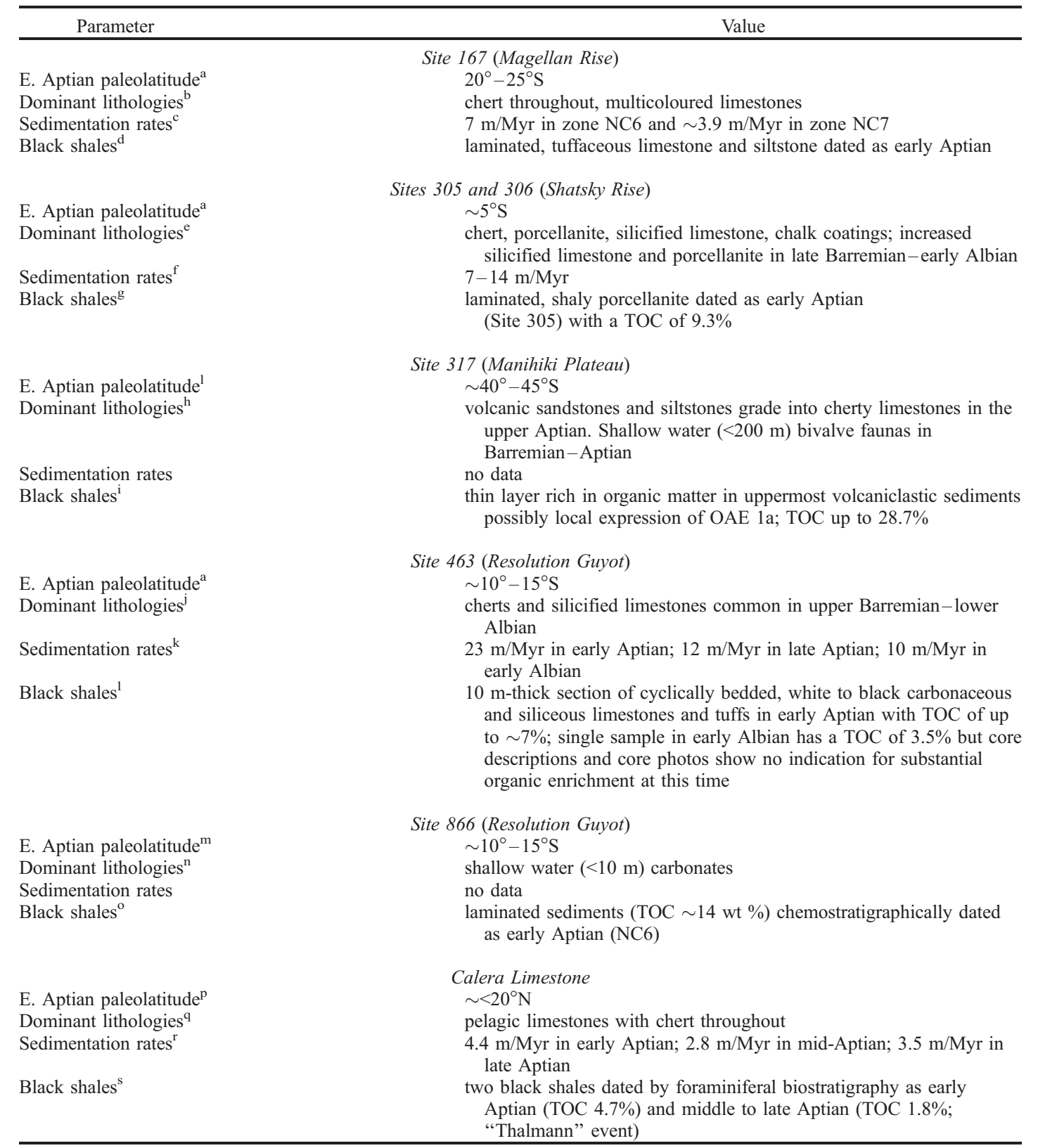

${ }^{a}$ Based on the position of Site 1213 in the early Aptian.

${ }^{\mathrm{b}}$ From Winterer et al. [1973].

${ }^{\mathrm{c}}$ Based on Bralower et al. [1994].

${ }^{\mathrm{d}}$ From Winterer et al. [1973], Tarduno et al. [1989], Sliter [1989], and Bralower et al. [1993, 1994].

${ }^{\mathrm{e}}$ From Larson et al. [1975] and Matter et al. [1975].

f From Larson et al. [1975].

${ }^{\mathrm{g}}$ From Bode [1975] and Sliter [1989].

${ }^{\mathrm{h}}$ From Jenkyns [1976] and Kauffman [1976].

${ }^{\mathrm{i}}$ From Jenkyns [1976] and Sliter [1989].

${ }^{\mathrm{j}}$ From Thiede et al. [1981].

${ }^{\mathrm{k}}$ Based on Sliter [1989], Bralower et al. [1994], and Erba [1994].

${ }^{1}$ From Mélières et al. [1981], Thiede et al. [1981], and Sliter [1989].

${ }^{\mathrm{m}}$ From Jenkyns and Wilson [1999].

${ }^{\mathrm{n}}$ From Sager et al. [1993].

${ }^{\circ}$ From Baudin et al. [1995], Jenkyns [1995], and Jenkyns and Wilson [1999].

${ }^{\mathrm{p}}$ From Sliter [1989].

${ }^{\mathrm{q}}$ From Wachs and Hein [1974, 1975] and Jenkyns [1980].

${ }^{\mathrm{r}}$ From Sliter [1999].

${ }^{\mathrm{s}}$ From Sliter [1989, 1999]. 
conditions controlling productivity and preservation of organic matter during OAE 1a [Bralower et al., 2002]. However, at Site 463 and Site 866 terrestrially sourced organic matter is also present, consistent with occasional redeposition of shallow water material on the flanks of a sea mount (Site 463) and deposition in extremely shallow water (Site 866). The record of OAE 1a at Site 317 also displays evidence for marine and terrestrial sources of organic matter [Simoneit and Struermer, 1982], consistent with the proposed shallow water depth [Kauffman, 1976].

[31] Unlike the records of OAE 1a described here, other Aptian-Albian organic-carbon-rich horizons in the Pacific basin do not appear to be widespread and are often geographically isolated. The late Aptian "Thalmann" event is only recorded in the Calera Limestone [Sliter, 1999]. Carbonized higher plant matter of a probable late Aptian age was recovered within basalt at Site 462 [Jenkyns and Schlanger, 1981] but the context and significance of this discovery is unclear. The only significant accumulation of organic-carbon-rich sediments in the Albian occurs in upper Albian laminated limestones from Site 465 and Site 466 on Hess Rise [Dean et al., 1981]. The organic matter in these limestones was from a marine source. These sediments may represent a record of OAE 1d [see Wilson and Norris, 2001] but it seems that their geographic distribution in the Pacific Ocean is limited only to these sites. The lack of evidence for black shales (with the exception of the lower Aptian sediments) in the truly pelagic Aptian-Albian facies on Shatsky Rise suggests that the occurrences elsewhere of organic-carbon-rich facies are indeed the result of localized phenomena.

\subsection{Oceanic Anoxic Events}

\subsubsection{Timing of OAEs Relative to the "Resistivity Highs"}

[32] Early Aptian sediments rich in organic carbon occur on Shatsky Rise and represent a Pacific Ocean expression of the global "Selli Event" (OAE 1a). On Shatsky Rise these sediments are associated with a "resistivity high" (lasting $\sim 5 \mathrm{Myr}$ ) that we interpret as reflecting increased biogenic silica flux and increased productivity consistent with other interpretations of OAE 1a [e.g., Premoli Silva et al., 1989; Weissert and Lini, 1991; Coccioni et al., 1992; Bralower et al., 1994; Erba, 1994; Erbacher et al., 1996; Menegatti et al., 1998; Paytan, 2003; Erba and Tremolada, 2004]. The early Albian "resistivity high" correlates to nannofossil subzones $\mathrm{NC} 8 \mathrm{a}$ and $\mathrm{NC} 8 \mathrm{~b}$ and lasted from $\sim 112$ to 107.5 Ma. While there is no evidence for significant deposition of organic carbon in the Pacific Ocean during this period of time, in the Atlantic and Tethyan Oceans widespread black shale deposition did occur [Bréhéret, 1985a, 1985b, 1988; Arthur et al., 1990; Bralower et al., 1993; Erbacher et al., 1996, 1998, 1999, 2001; Erbacher and Thurow, 1997; Kennedy et al., 2000; Kuypers et al., 2002; Leckie et al., 2002; Herrle et al., 2003a, 2003b, 2004; Luciani et al., 2004]. The peak of OAE $1 \mathrm{~b}$ represented by the Niveau Paquier in France (and equivalents in other regions) is biostratigraphically constrained to $H$. planispira planktonic foraminiferal Zone and the nannofossil subzone NC8a [e.g., Arthur et al., 1990; Bralower et al., 1993;
Erbacher et al., 1996] and has an approximate age of 111 Ma [Leckie et al., 2002]. However, Leckie et al. [2002] suggest that OAE $1 \mathrm{~b}$ occurred over a broader interval of time spanning $\sim 114-109 \mathrm{Ma}$ and resulted in the deposition of multiple black shale horizons, including the "Jacob" (upper Aptian), "Paquier" (lower Albian) and "Urbino" (lower Albian) events.

[33] Irrespective of which definition of OAE $1 \mathrm{~b}$ is utilized, organic carbon deposition in the Atlantic and Tethyan regions occurred at the same time as the deposition of high resistivity sediments on Shatsky Rise, interpreted here as an interval characterized by elevated productivity in the Pacific Ocean. The black shale records of OAE $1 \mathrm{~b}$ in the Tethyan and Atlantic regions (unlike those of OAE 1a) appear to be only partially caused by high productivity [see Bralower et al., 1993; Erbacher et al., 1996, 1998, 1999; Erbacher and Thurow, 1997; Herrle et al., 2003a, 2003b; Luciani et al., 2004]. Despite possible different mechanisms controlling organic carbon deposition during OAE $1 \mathrm{a}$ and OAE $1 \mathrm{~b}$ in the Atlantic and Tethyan regions, the coincidence of periods of increased productivity in the Pacific Ocean and the timing of OAE $1 \mathrm{a}$ and OAE $1 \mathrm{~b}$ is striking. This coincidence suggests causal relationships between high biosiliceous productivity and the generation of black shales in the Pacific basin during the Aptian-Albian.

\subsubsection{Volcanism}

[34] Many studies have cited the possible role of massive volcanism as a "driver" for Cretaceous OAEs [e.g., Force, 1984; Arthur et al., 1985; Weissert, 1989; Tarduno et al., 1991; Larson, 1991; Bralower et al., 1997; Sinton and Duncan, 1997; Jenkyns, 1999, 2003; Larson and Erba, 1999; Jones and Jenkyns, 2001; Leckie et al., 2002; Erba and Tremolada, 2004], although eustatic sea level change may also have been an important factor [e.g., Schlanger and Jenkyns, 1976; Jenkyns, 1980, 1985; Arthur et al., 1987; Schlanger et al., 1987]. Increased volcanism and seafloor spreading in the Barremian-early Aptian (including the submarine extrusion of the Hess Rise, Ontong-Java Plateau and the Manihiki Plateau) commenced at $\sim 125 \mathrm{Ma}$ [Bralower et al., 1997; Larson and Erba, 1999; McArthur et al., 2000; Jones and Jenkyns, 2001], and may have led to an increase in atmospheric $p \mathrm{CO}_{2}$ from the early Barremian to the Aptian [Tajika, 1999; Retallack, 2001; Wallmann, 2001; Robinson et al., 2002]. Greenhouse conditions in the early Aptian may have been exacerbated by massive rapid effusion of volcanogenic $\mathrm{CO}_{2}$ [Arthur, 2003] or massive dissociation of methane hydrate [Jahren et al., 2001; Beerling et al., 2002]. During the late Aptian-early Albian the Southern Kerguelen Plateau and Elan Bank of Kerguelen Plateau were extruded at or above sea level [Schlich et al., 1989] possibly leading to increased atmospheric $p \mathrm{CO}_{2}$, although data are somewhat sparse and contradictory [e.g., Tajika, 1999; Retallack, 2001].

[35] Global warming caused by increased atmospheric $p \mathrm{CO}_{2}$ would have resulted in an intensified hydrological cycle and increased surface wind velocities [e.g., Barron and Washington, 1985; Weissert, 1989; Weissert et al., 1998; Jenkyns, 1999, 2003; Larson and Erba, 1999]. Intensification of the hydrological cycle would have resulted in an increased supply of nutrients to the ocean 


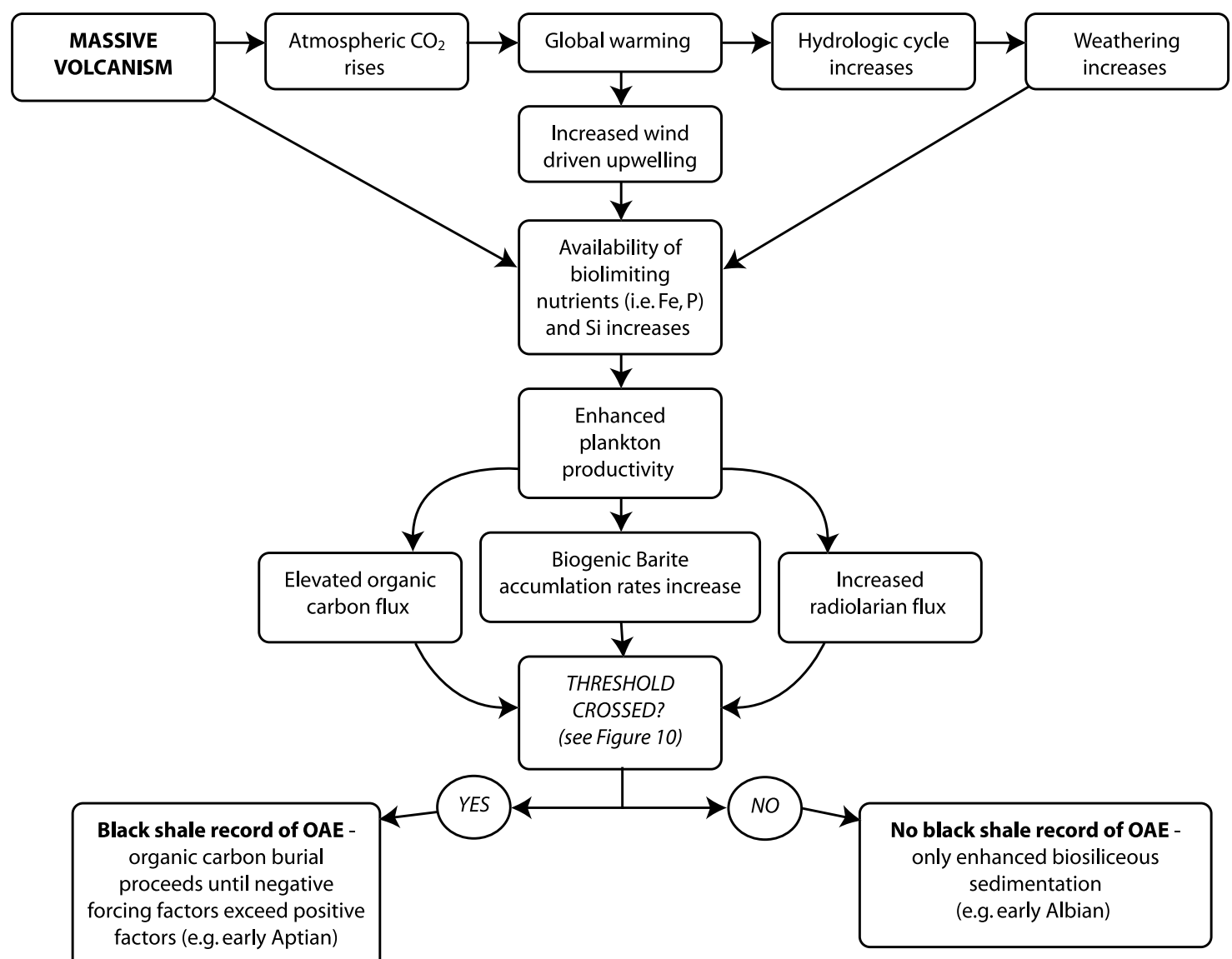

Figure 9. Schematic flowchart of events leading to deposition (or nondeposition) of sediments rich in organic carbon and biosiliceous material in the equatorial Pacific during the mid-Cretaceous. Flowchart is based upon this study, Jenkyns [2003, Figure 6] and Racki and Cordey [2000, Figures 8 and 12]. For simplicity, only the factors and events relevant to this study are included. For a fuller picture of the possible geological, geochemical, and paleoclimatic phenomena associated with OAEs, the reader is referred to Jenkyns [2003].

from weathering [e.g., Weissert, 1989; Weissert et al., 1998; Jenkyns, 1999, 2003; Larson and Erba, 1999; Wortmann et al., 2004] although whether this could efficiently "seed" the equatorial Pacific is doubtful. Higher surface wind velocities would have resulted in increased equatorial upwelling [e.g., Barron, 1985; Manabe and Bryan, 1985; Arthur et al., 1987; Barron and Moore, 1994] and potentially an increase in plankton productivity [Parrish and Curtis, 1982].

[36] Recent open ocean iron fertilization experiments have shown that flagellated phytoplankton (haptophytes (including coccoliths), pelagophytes and dinoflagellates) and diatoms bloom in response to the addition of iron to surface waters causing an increase in primary productivity, a reduction in $p \mathrm{CO}_{2}$ and nitrate concentrations, and, arguably, an increase in carbon export [e.g., Coale et al., 1996a, 1996b, 2004; Cooper et al., 1996; Ridgwell, 2000; Bishop et al., 2004; Buesseler et al., 2004]. It has been suggested that hydrothermal alteration of extrusive submarine volcanics in the Early Cretaceous may have supplied iron to the world ocean causing an increase in primary productivity [e.g.,
Sinton and Duncan, 1997; Larson and Erba, 1999; Leckie et al., 2002] resulting in an increase in the abundance of radiolarians and other mesotrophic and eutrophic organisms, at the expense of more oligotrophic plankton [e.g., Erba, 1994; Larson and Erba, 1999; Leckie et al., 2002; Erba and Tremolada, 2004]. A volcanogenic source of iron and other biolimiting nutrients does not preclude nutrification through increased equatorial upwelling and it is possible that both factors were important for the increased biosiliceous production observed on Shatsky Rise (Figure 9).

\subsubsection{Black Shale Formation: The "Organic Carbon Burial Threshold"}

[37] Once productivity was increased in the Early Cretaceous then the rate of organic carbon export would have risen resulting in an expansion of the oxygen minimum zone, thereby facilitating an increase in organic carbon burial rates and preservation. As a negative feedback, carbon was consumed and buried, $\mathrm{CO}_{2}$ was drawn down from the atmosphere, leading to a lessening of greenhouse conditions, which slowed riverine and upwelling nutrient supply to the oceans [Jenkyns, 1999, 2003]. Volcanogenic 


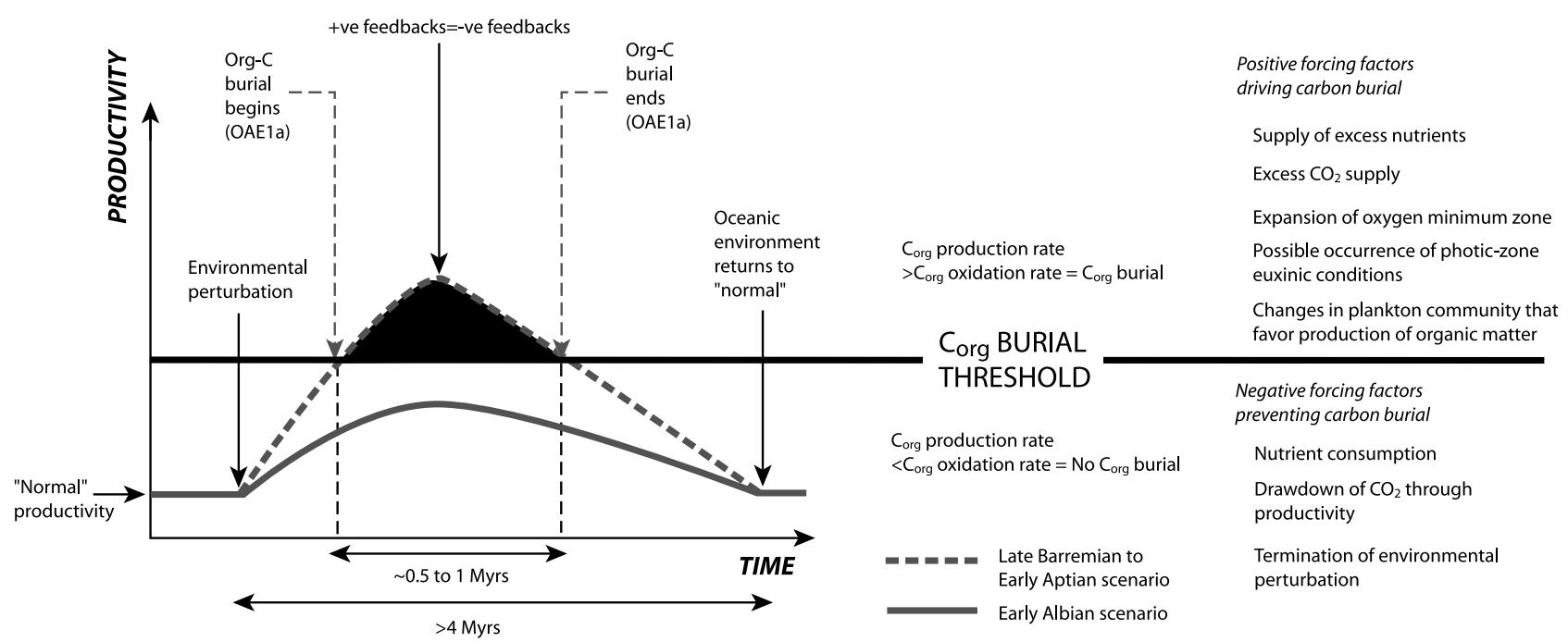

Figure 10. Conceptual model to explain the relationship between productivity, time, and black shale deposition in the Pacific Ocean. Note that the level of "normal" productivity and the level of the threshold may have been different in the late Barremian compared to the early Albian. Time estimates are based upon age model given in Figure 7.

nutrient supply became limited when the volcanic event terminated or slowed to such an extent that the "negative" forcing factors (e.g., nutrient uptake, atmospheric $\mathrm{CO}_{2}$ drawdown) became greater than the "positive" supply of nutrients. As nutrients were consumed and became depleted, carbon burial rates fell, leading to the cessation of the OAE and a gradual return to equilibrium conditions.

[38] Clearly, the organic carbon burial event is a special oceanographic state, which may only be reached once some threshold is crossed, such as the balance between primary productivity, carbon oxidation and carbon burial (Figures 9 and 10). With the exception of Site 317, all other records of OAE 1a in the Pacific Basin were within $20-25^{\circ}$ of the equator at the time of deposition, possibly within an expanded equatorial divergence zone [Bralower et al., 2002]. Site 317 was deposited in relatively shallow water and thus the black shale there may be the consequence of expansion of the oxygen minimum zone to shallow depths and terrestrial carbon input than marine productivity. However, without a truly pelagic record from a definitively oligotrophic area of the Pacific Ocean, it is impossible to ascertain whether increased productivity occurred everywhere, or whether it was restricted to zones of upwelling.

[39] Erba and Tremolada [2004] have suggested that a major re-organization of plankton communities commenced approximately 1.5 million years prior to OAE $1 \mathrm{a}$. The shift from oligotrophic to mesotrophic and eutrophic paleoceanographic conditions caused an increase in radiolarians, dinoflagellates and mesotrophic/eutrophic calcareous nannoplankton. M. Dumitrescu and S. C. Brassell (Biogeochemical assessment of paleoproductivity during the early Aptian oceanic anoxic event at Shatsky Rise, ODP Leg 198, submitted to Organic Geochemistry, 2004, hereinafter referred to as Dumitrescu and Brassell, submitted manuscript, 2004) note that lower carbonate saturation associated with high $p \mathrm{CO}_{2}$ would have favored noncalcareous plankton. The records of OAE 1a recovered during Leg 198 have biomarker distributions that are diagnostic of temporal fluctuations in phytoplankton abundance and population structure during OAE 1a including coccolithophores, cyanobacteria and dinoflagellates, suggesting that temporal fluctuations in nutrient abundance (especially depletion of nitrate) occurred (Dumitrescu and Brassell, submitted manuscript, 2004). Denitrification has been shown to be an important component of Mesozoic OAEs that allows $\mathrm{N}_{2}$-fixing cyanobacteria to proliferate [e.g., Jenkyns et al., 2001; Kuypers et al., 2004]. Thus, the threshold (Figure 10) for organic carbon burial in the Pacific Ocean may be a function of both enhanced productivity overwhelming organic carbon oxidation and changes in plankton community driven by nutrient availability and $p \mathrm{CO}_{2}$ that alter the ratio of organic to inorganic sedimentation.

[40] The frequent observation of radiolarites interbedded with black shale during OAEs [e.g., Schlanger and Jenkyns, 1976; Jenkyns, 1980, 1999; Arthur and Premoli Silva, 1982; Coccioni et al., 1987; Schlanger et al., 1987; Bréhéret, 1988; Sliter, 1989; Arthur et al., 1990; Kuhnt et al., 1990; Thurow et al., 1992; Bralower et al., 2002] could be a consequence of fluctuating nutrient conditions (that affected radiolarian food sources and symbionts), especially the availability of nitrate, iron and silica, possibly driven by episodic volcanism. The development of photic zone euxinic conditions during OAEs may also have facilitated enhanced organic carbon preservation [Pancost et al., 2004], although it has not yet been shown that such conditions existed on Shatsky Rise during OAE 1a. For the case of the early Albian it appears that the organic carbon burial threshold was never crossed in the Pacific Ocean (Figures 9 and 10), hence the absence of black shales of this age in the basin. The reason why the threshold was never attained in the early Albian is not certain but ultimately could be related to the rate and magnitude of volcanism 
driving global warming and productivity. Possibly of more fundamental importance was the geographic location and subaerial eruption of Kerguelen Plateau that would have limited the supply of nutrients to the Pacific Ocean through the hydrothermal alteration of basalt. However, an increase in greenhouse conditions could still have been driven in the early Albian through increased supply of volcanogenic $\mathrm{CO}_{2}$ to the atmosphere, ultimately leading to increased productivity via increased runoff and upwelling (Figure 9). Thus the critical factor in the Pacific basin, leading to black shale deposition in the early Aptian and nondeposition of black shale in the early Albian, may have been the input of hydrothermal nutrients. The scale and rate of volcanism (both LIP and mid-ocean ridge) in the early Albian was insufficient to reach the biological and chemical oceanographic conditions required to cross the black shale depositional threshold in the Pacific Ocean.

\section{Conclusions}

[41] 1. Downhole logs from ODP Leg 198 record changes in sediment porosity in the Lower Cretaceous that are most readily explained by increased siliceous cementation with the silica most likely being supplied by radiolarians.

[42] 2. Increased flux of biosiliceous production on Shatsky Rise was most likely caused by increased nutrient supply, possibly driven by equatorial upwelling and iron fertilization related to submarine volcanism.

[43] 3. Enhanced productivity occurred in the Pacific Ocean from $>2$ Myr prior to OAE 1a and continued for 3 Myr after. This sedimentary pattern suggests that paleoceanographic and environmental perturbations (possibly driven by massive volcanism) lasted much longer than just the interval of time during which organic carbon burial occurred.

[44] 4. In the early Albian enhanced productivity in the Pacific Ocean lasted approximately $4 \mathrm{Myr}$ and temporally spanned the period of time during which OAE $1 \mathrm{~b}$ (early Albian) occurred in the Tethys and Atlantic Oceans. This is the first documentation of paleoceanographic change in the Pacific Ocean that is concurrent with OAE 1b.

[45] 5. The absence of black shale in the early Albian in the Pacific Ocean suggests that, despite increased productivity, an oceanographic threshold must be crossed before organic carbon can accumulate. The nature of this threshold is unclear but may be a critical balance between increased productivity (that emphasizes organic matter production), the rate of carbon burial and the rate of carbon oxidation. These factors are possibly related to the availability of biolimiting nutrients and the rate of greenhouse warming associated with volcanic outgassing of $\mathrm{CO}_{2}$.

[46] Acknowledgments. This research used samples and data provided by the Ocean Drilling Program (ODP). ODP is sponsored by the U.S National Science Foundation (NSF) and participating countries under management of Joint Oceanographic Institutions (JOI), Inc. Robinson and Bown acknowledge the support of UK ODP and NERC (UK) for their participation aboard Leg 198. Discussion with Tim Bralower, Hugh Jenkyns, Adina Paytan, Isabella Premoli Silva and the members of the Leg 198 shipboard scientific party is gratefully acknowledged. LamontDoherty Earth Observatory provided partial support for this research. We are grateful for the thorough reviews of Tim Bralower, Elisabetta Erba and Hugh Jenkyns and the editing of Larry Peterson that significantly improved earlier versions of this work. This is LDEO contribution 6674.

\section{References}

Anderson, O. R. (1983), Radiolaria, 355 pp., Springer-Verlag, New York.

Andrews, J. E., et al. (1975), Initial Reports of the Deep Sea Drilling Project, vol. 30, U.S. Govt. Print. Off., Washington, D. C.

Arthur, M. A. (2003), On the origin of Mesozoic oceanic anoxic events (OAEs): An overview, Eos Trans. AGU, 84(46), Fall Meet. Suppl., Abstract PP42Cg3-01.

Arthur, M. A., and I. Premoli Silva (1982), Development of widespread organic carbonrich strata in the Mediterranean Tethys, in Nature and Origin of Cretaceous CarbonRich Facies, edited by S. O. Schlanger and M. B. Cita, pp. 7-54, Academic, San Diego, Calif.

Arthur, M. A., W. E. Dean, and S. O. Schlanger (1985), Variations in the global carbon cycle during the Cretaceous related to climate, volcanism, and changes in atmospheric $\mathrm{CO}_{2}$, in The Carbon Cycle and Atmospheric $\mathrm{CO}_{2}$ : Natural Variations Archean to Present, Geophys. Monogr. Ser, vol. 32, edited by E. T. Sundquist and W. S. Broecker, pp. 504-529, AGU, Washington, D. C.

Arthur, M. A., S. O. Schlanger, and H. C. Jenkyns (1987), The Cenomanian-Turonian oceanic anoxic event, II. Palaeoceanographic controls on organic-matter production and preservation, in Marine Petroleum Source Rocks, Geol. Soc. Spec. Publ., vol. 26, edited by J. Brooks and A. J. Fleet, pp. 401-420, Geol. Soc., London.
Arthur, M. A., H. C. Jenkyns, H.-J. Brumsack, and S. O. Schlanger (1990), Stratigraphy, geochemistry, and paleoceanography of organic carbon-rich Cretaceous sequences, in Cretaceous Resources, Events and Rhythms, edited by R. N. Ginsburg and B. Beaudoin, pp. 75119, Kluwer Acad., Norwell, Mass.

Barron, E. J. (1985), Numerical climate modelling, a frontier in petroleum source rock prediction: Results based on Cretaceous simulations, AAPG Bull., 69, 448-459.

Barron, E. J., and G. T. Moore (1994), Climate model application in paleoenvironmental analysis, SEPM Short Course 33, Soc. for Sediment. Geol., Tulsa, Okla.

Barron, E. J., and W. M. Washington (1985), Warm Cretaceous climates, high atmospheric $\mathrm{CO}_{2}$ as a plausible mechanism, in The Carbon Cycle and Atmospheric $\mathrm{CO}_{2}$ : Natural Variations Archean to Present, Geophys. Monogr. Ser., vol. 32, edited by E. T. Sundquist and W. S. Broecker, pp. 546-553, AGU, Washington, D. C.

Baudin, F., J.-F. Deconinck, R. F. Sachsenhofer, A. Strasser, and H. Arnaud (1995), Organic geochemistry and clay mineralogy of lower Cretaceous sediments from Allison and Resolution Guyots (Sites 865 and 866), mid-Pacific mountains, Proc. Ocean Drill. Program Sci. Results, 143, 173-196.

Baumgartner, P. O. (1987), Age and genesis of Tethyan Jurassic radiolarites, Eclogae Geol. Helv., 80, 831-879.
Beerling, D. J., M. R. Lomas, and D. R. Gröcke (2002), On the nature of methane gas-hydrate dissociation during the Toarcian and Aptian oceanic anoxic events, Am. J. Sci., 302, $28-$ 49.

Bishop, J. K. B., T. J. Wood, R. E. Davis, and J. T. Sherman (2004), Robotic observations of enhanced carbon biomass export at $55^{\circ} \mathrm{S}$ during SOFex, Science, 304, 417-420.

Bode, G. W. (1975), Carbon and carbonate analyses, Leg 32, Initial Rep. Deep Sea Drill. Project, 32, 561-562.

Bralower, T. J., W. V. Sliter, M. A. Arthur, R. M Leckie, D. Allard, and S. O. Schlanger (1993), Dysoxic/anoxic episodes in the Aptian-Albian (Early Cretaceous), in The Mesozoic Pacific: Geology, Tectonics, and Volcanism, Geophys. Monogr. Ser, vol. 77, edited by M. S. Pringle et al., pp. 5-37, AGU, Washington, D. C.

Bralower, T. J., M. A. Arthur, R. M. Leckie, W. V. Sliter, D. J. Allard, and S. O. Schlanger (1994), Timing and paleoceanography of oceanic dysoxia/anoxia in the late Barremian to early Aptian (Early Cretaceous), Palaios, 9, 335369.

Bralower, T. J., R. M. Leckie, W. V. Sliter, and H. R. Thierstein (1995), An integrated Cretaceous microfossil biostratigraphy, in Geochronology, Time Scales and Global Stratigraphic Correlation, Spec. Publ. SEPM Soc. Sediment. Geol., vol. 54, edited by W. A. Berggren et al., pp. 65-70, Soc. for Sediment. Geol., Tulsa, Okla. 
Bralower, T. J., P. D. Fullagar, C. K. Paull, G. S. Dwyer, and R. M. Leckie (1997), MidCretaceous strontium-isotope stratigraphy of deep-sea sections, Geol. Soc. Am. Bull., 109, $1421-1442$.

Bralower, T. J., et al. (2002), Proceedings of the Ocean Drilling Program, Initial Reports [CD-ROM], vol. 198, Ocean Drill. Program, College Station, Tex.

Bréhéret, J.-G. (1985a), Indices d'un événement anoxique étendu à la Téthys alpine, à l'Albien inférieur (événement Paquier), C. R. Acad. Sci., Paris Sér. 2, 300, 355-358.

Bréhéret, J.-G. (1985b), Sedimentologie et diagenese de la matiere organique contenue dans le niveau Paquier, couche repere de l'Albien inferieur vocontien, C. R. Acad. Sci., Paris Sér. 2, 301, 1151-1156.

Bréhéret, J.-G. (1988), Épisodes de sedimentation riche en matière organique dans les marnes bleues d'âge aptien et albien de la partie pélagique du basin vocontien, Bull. Soc. Geol. Fr. Ser. 8, 4, 349-356.

Broecker, W. S., and T. S. Peng (1982), Tracers in the Sea, LDGO Press, Palisades, N. Y.

Buesseler, K. O., J. E. Andrews, S. M. Pike, and M. A. Charette (2004), The effects of iron fertilization on carbon sequestration in the Southern Ocean, Science, 304, 414417.

Burkle, L. H. (1998), Marine diatoms, in Introduction to Marine Micropaleontology, 2nd ed., edited by B. U. Haq and A. Boersma, pp. 245266, Elsevier Sci., New York.

Channell, J. E. T., E. Erba, M. Nakanishi, and K. Tamaki (1995), Late Jurassic-Early Cretaceous time scales and oceanic magnetic anomaly block models, in Geochronology, Time Scales and Global Stratigraphic Correlation, Spec. Publ. SEPM Soc. Sediment. Geol., vol. 54, edited by W. A. Berggren et al., pp. 51-63, Soc. for Sediment. Geol., Tulsa, Okla.

Coale, K. H., S. E. Fitzwater, R. M. Gordon, K. S. Johnson, and R. T. Barber (1996a), Control of community growth and export production by upwelled iron in the equatorial Pacific Ocean, Nature, 379, 621-624.

Coale, K. H., et al. (1996b), A massive phytoplankton bloom induced by an ecosystemscale iron fertilization experiment in the equatorial Pacific Ocean, Nature, 383, 495-501.

Coale, K. H., et al. (2004), Southern Ocean iron enrichment experiment: Carbon cycling in high- and low-Si waters, Science, 304, 408414.

Coccioni, A., O. Nesci, M. Tramontana, F. C. Wezel, and E. Moretti (1987), Descrizione di un livello-guida "Radiolaritico-bituminoso ittiolitico" alla base delle marne a fucoidi nell'Appennino umbro-marchigiano, Boll. Soc. Geol. Ital., 106, 183-192.

Coccioni, R., R. Franchi, O. Nesci, F.-C. Wezel, F. Battistini, and P. Pallechi (1989), Stratigraphy and mineralogy of the Selli Level (early Aptian) at the base of the Marne a Fucoidi in the Umbro-Marchean Appenines (Italy), in Cretaceous of the Western Tethys, Proceedings of the 3rd International Cretaceous Symposium, edited by J. Wiedmann and T. Birkelund, pp. 563-584, Schweizerbart, Stuttgart, Germany,

Coccioni, R., E. Erba, and I. Premoli-Silva (1992), Barremian-Aptian calcareous plankton biostratigraphy from the Gorgo Cerbara section (Marche, central Italy) and implications for plankton evolution, Cretaceous Res., $13,517-537$.
Cooper, D. J., A. J. Watson, and P. D. Nightingale (1996), Large decrease in ocean-surface $\mathrm{CO}_{2}$ fugacity in response to in situ iron fertilization, Nature, 383, 511-513.

Dean, W. E., G. E. Claypool, and J. Thiede (1981), Origin of organic-carbon-rich midCretaceous limestones, Mid-Pacific Mountains and Southern Hess Rise, Initial Rep. Deep Sea Drill. Project, 62, 877-890.

De Wever, P. (1994), Radiolarians and radiolarites, C. R. Acad. Sci. Paris Sér. 2, 319, 513526.

De Wever, P., and F. Baudin (1996), Palaeogeography of radiolarite and organic-rich deposits in Mesozoic Tethys, Geol. Rundsch., 85, 310326.

Erba, E. (1992), Middle Cretaceous calcareous nannofossils from the western Pacific (Leg 129), Evidence for paleoequatorial crossings, Proc. Ocean Drill. Program Sci. Results, 129, 189-201

Erba, E. (1994), Nannofossils and superplumes: The early Aptian "nannoconid crisis," Paleoceanography, 9, 483-501.

Erba, E., and F. Tremolada (2004), Nannofossil carbonate fluxes during the Early Cretaceous: Phytoplankton response to nutrification episodes, atmospheric $\mathrm{CO}_{2}$, and anoxia, Paleoceanography, 19, PA1008, doi:10.1029/ 2003PA000884.

Erbacher, J., and J. Thurow (1997), Influence of oceanic anoxic events on the evolution of midCretaceous radiolaria in the North Atlantic and western Tethys, Mar. Micropaleontol., 30, $139-158$.

Erbacher, J., J. Thurow, and R. Littke (1996), Evolution patterns of radiolaria and organic matter variations: A new approach to identify sea-level changes in mid-Cretaceous pelagic environments, Geology, 24, 499-502.

Erbacher, J., W. Gerth, G. Schmiedl, and C. Hemleben (1998), Benthic foraminiferal assemblages of late Aptian-early Albian black shale intervals in the Vocontian Basin, SE France, Cretaceous Res., 19, 805-826.

Erbacher, J., C. Hemleben, B. T. Huber, and M. Markey (1999), Correlating environmental changes during the early Albian oceanic anoxic event $1 \mathrm{~B}$ using benthic foraminiferal paleocology, Mar. Micropaleontol., 38, $7-$ 28.

Erbacher, J., B. T. Huber, R. D. Norris, and M. Markey (2001), Increased thermohaline stratificiation as a possible cause for an oceanic anoxic event in the Cretaceous period, Nature, 409, 325-327.

Ewing, M., T. Saito, J. Ewing, and L. H Burckle (1966), Lower Cretaceous sediments from the northwest Pacific, Science, 152, $751-755$.

Fischer, A. G., et al. (1971), Initial Reports of the Deep Sea Drilling Project, vol. 6, U.S. Govt. Print. Off., Washington, D. C.

Force, E. R. (1984), A relation among geomagnetic reversals, seafloor spreading rate, paleoclimate, and black shales, Eos Trans. AGU, 65, $18-19$.

Gersonde, R., and D. M. Harwood (1990), Lower Cretaceous diatoms from ODP Leg 113 Site 693 (Weddell Sea), Part 1, Vegetative cells, Proc. Ocean Drill. Program Sci. Results, 113, 365-402.

Gradstein, F. M., F. P. Agterberg, J. G. Ogg, J. Hardenbol, P. van Veen, J. Thierry, and Z. Huang (1995), A Triassic, Jurassic and Cretaceous time scale, in Geochronology, Time Scales and Global Stratigraphic Correlation, Spec. Publ. SEPM Soc. Sediment. Geol., vol. 54, edited by W. A. Berggren et al., pp. 95-126, Soc. for Sediment. Geol., Tulsa, Okla

Harper, H. E., Jr., and A. H. Knoll (1975), Silica, diatoms, and Cenozoic radiolarian evolution, Geology, 3, 175-177.

Harwood, D. M., and R. Gersonde (1990), Lower Cretaceous diatoms from ODP Leg 113 Site 693 (Weddell Sea), part 2, Resting spores, Proc. Ocean Drill. Program Sci. Results, 113, 403-426.

Heath, G. R., et al. (1985), Initial Reports of the Deep Sea Drilling Project, vol. 86, U.S. Govt. Print. Off., Washington, D. C.

Herrle, J. O., J. Pross, O. Friedrich, and C. Hemleben (2003a), Short-term environmental changes in the Cretaceous Tethyan Ocean: Micropalaeontological evidence from the early Albian oceanic anoxic event 1b, Terra Nova, 15, 14-19.

Herrle, J. O., J. Pross, O. Friedrich, P. Kößler, and C. Hemleben (2003b), Forcing mechanisms for mid-Cretaceous black shale formation: Evidence from the upper Aptian and lower Albian of the Vocontian Basin (SE France), Palaeogeogr. Palaeoclimatol. Palaeoecol., 190, 399-426.

Herrle, J. O., P. Kößler, O. Friedrich, H. Erlenkeuser, and C. Hemleben (2004), High-resolution carbon isotope records of the Aptian to lower Albian from SE France and the Mazagan Plateau (DSDP Site 545), A stratigraphic tool for paleoceanographic and paleobiologic reconstruction, Earth Planet. Sci. Lett., 218, 149-161.

Jackson, P. D., D. G. Gunn, R. C. Flint, D. Beamish, P. I. Meldrum, M. A. Lovell, P. K. Harvey, and A. Peyton (1997), A noncontacting resistivity imaging method for characterizing whole round core while in its liner, in Developments in Petrophysics, Geol. Soc. Spec. Publ., vol. 122, edited by M. A. Lovell and P. K. Harvey, pp. 1-10, Geol. Soc., London.

Jackson, P. D., P. K. Harvey, M. A. Lovell, D. A. Gunn, C. G. Williams, and R. C. Flint (1998), Measurement scale and formation heterogeneity: Effects on the integration of resistivity data, in Core-Log Integration, Geol. Soc. Spec Publ., vol. 136, edited by P. K. Harvey and M. A. Lovell, pp. 261-272, Geol. Soc., London.

Jahren, A. H., N. C. Arens, G. Sarmiento, J. Guerrero, and R. Amundson (2001), Terrestrial record of methane hydrate dissociation in the Early Cretaceous, Geology, 29, 159-162.

Jenkyns, H. C. (1976), Sediments and sedimentary history of the Manihiki Plateau, South Pacific Ocean, Initial Rep. Deep Sea Drill. Project, 33, 873-890

Jenkyns, H. C. (1980), Cretaceous anoxic events: From continents to oceans, J. Geol. Soc. London, 137, 171-188.

Jenkyns, H. C. (1985), The early Toarcian and Cenomanian-Turonian anoxic events in Europe: Comparison and contrasts, Geol. Rundsch., 74, 505-518.

Jenkyns, H. C. (1995), Carbon-isotope stratigraphy and paleoceanographic significance of the Lower Cretaceous shallow-water carbonates of resolution Guyot, mid-Pacific mountains, Proc. Ocean Drill. Program Sci. Results, 143, 99-104.

Jenkyns, H. C. (1999), Mesozoic anoxic events and palaeoclimate, Zentrallbl. Geol. Palaontol. Teil 1, 1997, 943-949.

Jenkyns, H. C. (2003), Evidence for rapid climate change in the Mesozoic-Palaeogene 
greenhouse world, Philos. Trans. R. Soc. London Ser. A, 361, 1885-1916.

Jenkyns, H. C., and S. O. Schlanger (1981), Significance of plant remains in redeposited Aptian sediments, Hole 642A, Nauru Basin, to Cretaceous oceanic-oxygenation models, Initial Rep. Deep Sea Drill. Project, 61, 557562.

Jenkyns, H. C., and P. A. Wilson (1999), Stratigraphy, paleoceanography, and evolution of Cretaceous Pacific Guyots: Relics from a greenhouse earth, Am. J. Sci., 299, 341-392.

Jenkyns, H. C., and E. L. Winterer (1982), Palaeoceanography of Mesozoic ribbon radiolarites, Earth Planet. Sci. Lett., 60, 351-375.

Jenkyns, H. C., D. R. Gröcke, and S. P. Hesselbo (2001), Nitrogen isotope evidence for water mass denitification during the early Toarcian (Jurassic) oceanic anoxic event, Paleoceanography, 16, 593-603.

Jones, C. E., and H. C. Jenkyns (2001), Seawater strontium isotopes, oceanic anoxic events, and seafloor hydrothermal activity in the Jurassic and Cretaceous, Am. J. Sci., 301, 112-149.

Kauffman, E. G. (1976), Deep-sea Cretaceous macrofossils: Hole 317A, Manihiki Plateau, Initial Rep. Deep Sea Drill. Project, 33, 503-528.

Keene, J. B. (1975), Cherts and porcellanites from the North Pacific, DSDP Leg 32, Initial Rep. Deep Sea Drill. Project, 32, 429-507.

Kennedy, W. J., A. S. Gale, P. R. Bown, M. Caron, R. J. Davey, D. Gröcke, and D. S. Wray (2000), Integrated stratigraphy across the Aptian-Albian boundary in the Marnes Bleues, at the Col de Pré-Guittard, Arnayon (Drôme), and at Tartonne (Alpes-de-HauteProvence), France: A candidate global boundary stratotype section and boundary point for the base of the Albian stage, Cretaceous Res., $21,591-720$.

Kroenke, L. W., et al. (1991), Proceedings of the Ocean Drilling Program, Initial Reports, vol. 130, Ocean Drill. Program, College Station, Tex.

Kuhnt, W., J. P. Herbin, J. Thurow, and J. Wiedmann (1990), Distribution of Cenomanian-Turonian organic facies in the western Mediterranean and along the adjacent Atlantic margin, in Deposition of Organic Facies, AAPG Stud. Geol., vol. 30, edited by A. Y. Huc, pp. 133-160, Soc. for Sediment. Geol., Tulsa, Okla.

Kuypers, M. M. M., P. Blokker, E. C. Hopmans, H. Kinkel, R. D. Pancost, S. Schouten, and J. S. Sinninghe Damsté (2002), Archaeal remains dominate marine organic matter from the early Albian oceanic anoxic event 1b, Palaeogeogr. Palaeoclimatol. Palaeoecol., $185,211-234$

Kuypers, M. M. M., Y. van Breugel, S. Schouten, E. Erba, and J. S. Sinninghe Damsté (2004), $\mathrm{N}_{2}$-fixing cyanobacteria supplied nutrient $\mathrm{N}$ for Cretaceous oceanic anoxic events, Geology, $32,853-856$

Larson, R. L. (1991), Geological consequences of superplumes, Geology, 19, 963-966.

Larson, R. L., and E. Erba (1999), Onset of mid-Cretaceous greenhouse in the Barremian-Aptian: Igneous events and the biological, sedimentary, and geochemical responses, Paleoceanography, 14, 663-678.

Larson, R. L., et al. (1975), Initial Reports of the Deep Sea Drilling Project, vol. 32, U.S. Govt. Print. Off., Washington, D. C.

Larson, R. L., M. B. Steiner, E. Erba, and Y. Lancelot (1992), Paleolatitudes and tectonic reconstructions of the oldest portion of the
Pacific plate: A comparative study, Proc. Ocean Drill. Program Sci. Results, 129, 615-631.

Leckie, R. M. (1984), Mid-Cretaceous planktonic foraminiferal biostratigraphy off central Morocco, Deep Sea Drilling Project Leg 79, sites 545 and 547, Initial Rep. Deep Sea Drill. Project, 79, 579-620.

Leckie, R. M., T. J. Bralower, and R. Cashman (2002), Oceanic anoxic events and plankton evolution: Biotic response to tectonic forcing during the mid-Cretaceous, Paleoceanography, 17(3), 1041, doi:10.1029/2001PA000623.

Leinen, M., D. Cwienk, G. R. Heath, P. E. Biscaye, V. Kolla, J. Thiede, and J. P. Dauphin (1986), Distribution of biogenic silica and quartz in recent deep-sea sediments, Geology, 14, 199-203.

Lisitzin, A. P. (1972), Sedimentation in the World Ocean, SEPM Spec. Publ., vol. 17, 218 pp. Soc. for Sediment. Geol., Tulsa, Okla.

Luciani, V., M. Cobianchi, and H. C. Jenkyns (2004), Albian high-resolution biostratigraphy and isotope stratigraphy: The Coppa della Nuvola pelagic succession of the Gargano Promontory (southern Italy), Eclogae Geol. Helv., 97, 77-92.

Mahoney, J. J., et al. (2001), Proceedings of the Ocean Drilling Program, Initial Reports [CD-ROM], vol. 192, Ocean Drill. Program, College Station, Tex.

Maliva, R. G., A. H. Knoll, and R. Siever (1989), Secular change in chert distribution: A reflection of evolving biological participation in the silica cycle, Palaios, 4, 519-532.

Manabe, S., and K. Bryan (1985), CO2-induced change in a coupled ocean-atmosphere mode and its paleoclimatic implications, J. Geophys Res., 90, 11,689-11,707.

Matter, A., R. G. Douglas, and K. Perch-Nielsen (1975), Fossil preservation, geochemistry, and diagenesis of pelagic carbonates from Shatsky Rise, northwest Pacific, Initial Rep. Deep Sea Drill. Project, 32, 891-921.

McArthur, J. M., R. J. Howarth, and T. R. Bailey (2000), Strontium isotope stratigraphy: LOWESS version 3: Best fit to the marine Sr-isotope curve for 0-509 Ma and accompanying look-up table for deriving numerical age, J. Geol., 109, 155-170.

Mélières, F., G. Deroo, and J.-P. Herbin (1981), Organic-matter-rich and hypersiliceous Aptian sediments from western mid-Pacific mountains, Deep Sea Drilling Project Leg 62, Initial Rep. Deep Sea Drill. Project, 62, 903-921.

Menegatti, A. P., H. Weissert, R. S. Brown, R. V. Tyson, P. Farrimond, A. Strasser, and M. Caron (1998), High-resolution $\delta^{13} \mathrm{C}$ stratigraphy through the early Aptian "Livello Selli" of the Alpine Tethys, Paleoceanography, 13, 530-545.

Miskell, K. J., G. W. Brass, and C. G. A. Harrison (1985), Global patterns in opal deposition from Late Cretaceous to late Miocene, AAPG Bull., 69, 996-1012.

Nakanishi, M., K. Tamaki, and K. Kobayashi (1989), Mesozoic magnetic anomaly lineations and seafloor spreading history of the northwestern Pacific, J. Geophys. Res., 94, 15,43715,462

Ogg, J. G., S. M. Karl, and R. J. Behl (1992), Jurassic through Early Cretaceous sedimentation history of the central equatorial Pacific and of sites 800 and 801, Proc. Ocean Drill. Program Sci. Results, 129, 571-613.

Pancost, R. D., N. Crawford, S. Magness, A. Turner, H. C. Jenkyns, and J. R. Maxwell
(2004), Further evidence for the development of photic-zone euxinic conditions during Mesozoic oceanic anoxic events, J. Geol. Soc. London, 161, 353-364.

Parrish, J. T., and R. L. Curtis (1982), Atmospheric circulation, upwelling, and organicrich rocks in the Mesozoic and Cenozoic eras, Palaeogeogr. Palaeoclimatol. Palaeoecol., 40, $31-66$.

Paytan, A. (2003), Tales of black shales: Barite accumulation rates in Cretaceous sediments, in Ocean Drilling Program Highlights, January 2003, edited by K. White and E. Urquhart, p. 11, Jt. Oceanogr. Inst., Washington, D. C. (Available at http://www.oceandrilling.org/ greatest hits $2 /$ )

Premoli Silva, I., E. Erba, and M. E. Tornaghi (1989), Paleoenvironmental signals and changes in surface fertility in mid Cretaceous Corg-rich pelagic facies of the Fucoid Marls (central Italy), Geobios Mem. Spec., 11, $225-236$.

Racki, G., and F. Cordey (2000), Radiolarian palaeoecology and radiolarites: Is the present the key to the past?, Earth Sci. Rev., 52, 83120.

Renz, G. W. (1976), The distribution and ecology of radiolaria in the central Pacific: Plankton and surface sediments, Bull. Scripps Inst. Oceanogr., 22, 1-267.

Retallack, G. J. (2001), A 300-million-year record of atmospheric carbon dioxide from fossil plant cuticles, Nature, 411, 287-290.

Ridgwell, A. J. (2000), Climatic effect of Southern Ocean Fe fertilization: Is the jury still out? Geochem. Geophys. Geosyst., 1, doi:10.1029/ 2000GC000120

Robinson, S. A., J. E. Andrews, S. P. Hesselbo, J. D. Radley, P. F. Dennis, I. C. Harding, and P. Allen (2002), Atmospheric $\mathrm{pCO}_{2}$ and depositional environment from stable-isotope geochemistry of calcrete nodules (Barremian, Lower Cretaceous, Wealden Beds, England), J. Geol. Soc. London, 159, 215-224.

Sager, W. W., and A. A. P. Koppers (2000), Late Cretaceous polar wander of the Pacific Plate: Evidence of a rapid true polar wander event, Science, 287, 455-459.

Sager, W. W., D. W. Handschumacher, T. W. C. Hilde, and D. R. Bracey (1988), Tectonic evolution of the northern Pacific Plate and Pacific-Farallon-Izanagi triple junction in the Late Jurassic and Early Cretaceous (M21M10), Tectonophysics, 155, 345-364.

Sager, W. W., et al. (1993), Proceedings of the Ocean Drilling Program, Initial Reports, vol. 143, Ocean Drill. Program, College Station, Tex.

Schlanger, S. O., and R. G. Douglas (1974), The pelagic ooze-chalk-limestone transition and its implications for marine stratigraphy, in Pelagic Sediments: On Land and Under the Sea, Spec. Publ., vol. 1, edited by K. J. Hsü and H. C. Jenkyns, pp. 117-148, Int. Assoc. of Sedimentol.

Schlanger, S. O., and H. C. Jenkyns (1976), Cretaceous oceanic anoxic events: Causes and consequences, Geol. Mijnbouw, 55, 179-184.

Schlanger, S. O., et al. (1976), Initial Reports of the Deep Sea Drilling Project, vol. 33, U.S. Govt. Print. Off., Washington, D. C.

Schlanger, S. O., M. A. Arthur, H. C. Jenkyns, and P. A. Scholle (1987), The CenomanianTuronian oceanic anoxic event: I, Stratigraphy and distribution of organic carbon-rich beds and the marine delta $\delta^{13} \mathrm{C}$ excursion, in Marine Petroleum Source Rocks, Geol. Soc. Spec. Publ., vol. 26, edited by 
J. Brooks and A. J. Fleet, pp. 371-399, Geol. Soc., London.

Schlich, R., et al. (1989), Proceedings of the Ocean Drilling Program, Initial Reports, vol. 120, Ocean Drill. Program, College Station, Tex.

Schlumberger Educational Services (1989), Log Interpretation, Principles/Applications, 198 pp., Houston, Tex.

Scholle, P. A., and M. A. Arthur (1980), Carbon isotope fluctuations in Cretaceous pelagic limestones: Potential stratigraphic and petroleum exploration tool, $A A P G$ Bull., 64, 67-87.

Simoneit, B. R. T., and D. H. Struermer (1982), Organic geochemical indicators for sources of organic matter and paleoenvironmental conditions in Cretaceous oceans, in Nature and Origin of Cretaceous Carbon-Rich Facies, edited by S. O. Schlanger and M. B. Cita, pp. 145163, Academic, San Diego, Calif.

Sinton, C. W., and R. A. Duncan (1997), Potential links between ocean plateau volcanism and global ocean anoxia at the CenomanianTuronian boundary, Econ. Geol., 92, 836842.

Sliter, W. V. (1989), Aptian anoxia in the Pacific Basin, Geology, 17, 909-912.

Sliter, W. V. (1999), Cretaceous planktic foraminiferal biostratigraphy of the Calera Limestone, northern California, USA, J. Foraminiferal Res., 29, 318-339.

Tajika, E. (1999), Carbon cycle and climate change during the Cretaceous inferred from a biogeochemical carbon cycle model, Isl. Arc, 8, 293-303

Tarduno, J. A., W. V. Sliter, T. J. Bralower, M. McWilliams, I. Premoli-Silva, and J. G. Ogg (1989), M-sequence reversals recorded in DSDP sediment cores from the western mid-Pacific mountains and Magallen Rise, Geol. Soc. Am. Bull., 101, 1306-1316.

Tarduno, J. A., W. V. Sliter, L. Kroenke, M. Leckie, H. Mayer, J. J. Mahoney,
R. Musgrave, M. Storey, and E. L. Winterer (1991), Rapid formation of Ontong Java Plateau by Aptian mantle plume volcanism, Science, 254, 399-403.

Thiede, J., et al. (1981), Initial Reports of the Deep Sea Drilling Project, vol. 62, U.S. Govt. Print. Off., Washington, D. C.

Thurow, J., H.-J. Brumsack, J. Rullkötter, R. Littke, and P. Meyers (1992), The Cenomanian/Turonian boundary event in the Indian Ocean-A key to understand the global picture, in Synthesis of Results From Scientific Drilling in the Indian Ocean, Geophys. Monogr. Ser., vol. 20, edited by R. A. Duncan et al., pp. 253-273, AGU, Washington, D. C.

Tréguer, P., D. M. Nelson, A. J. Van Bennekom, D. J. DeMaster, A. Leynaert, and B. Quéguiner (1995), The silica balance in the world ocean: A reestimate, Science, 268, 375-379.

van der Lingen, G. J., and G. H. Packham (1975), Relationships between diagenesis and physical properties of biogenic sediments of the Ontong-Java Plateau (Sites 288 and 289, Deep Sea Drilling Project), Initial Rep. Deep Sea Drill. Proj., 30, 443-481.

Wachs, D., and J. R. Hein (1974), Petrography and diagenesis of Franciscan limestones, J. Sediment. Petrol., 44, 1217-1231.

Wachs, D., and J. R. Hein (1975), Franciscan limestones and their environments of deposition, Geology, 3, 29-33.

Wallmann, K. (2001), Controls on the Cretaceous and Cenozoic evolution of seawater composition, atmospheric $\mathrm{CO}_{2}$ and climate, Geochim. Cosmochim. Acta, 65, 3005-3025.

Wang, R., and A. Abelmann (2002), Radiolarian responses to paleoceanographic events in the southern South China Sea during the Pleistocene, Mar. Micropaleontol., 46, 25-44.

Weissert, H. (1989), C-isotope stratigraphy, a monitor of paleoenvironmental change: A case study from the Early Cretaceous, Surv. Geophys., 10, 1-16.
Weissert, H., and A. Lini (1991), Ice age interludes during the time of Cretaceous greenhouse climate?, in Controversies in Modern Geology: Evolution of Geological Theories in Sedimentology, Earth History and Tectonics, edited by D. W. Müller, J. A. McKenzie, and H. Weissert, pp. 173-191, Academic, San Diego, Calif.

Weissert, H., A. Lini, K. B. Föllmi, and O. Kuhn (1998), Correlation of Early Cretaceous carbon-isotope stratigraphy and platform drowning events: A possible link?, Palaeogeogr. Palaeoclimatol. Palaeoecol., 137 189-203.

Wilson, P. A., and R. D. Norris (2001), Warm tropical ocean surface and global anoxia during the mid-Cretaceous period, Nature, 412 , 425-429.

Wilson, P. A., H. C. Jenkyns, H. Elderfield, and R. L. Larson (1998), The paradox of drowned carbonate platforms and the origin of Cretaceous Pacific guyots, Nature, 392, 889-894.

Winterer, E. L., et al. (1973), Initial Reports of the Deep Sea Drilling Project, vol. 17, U.S. Govt. Print. Off., Washington, D. C.

Wortmann, U. G., J. O. Herrle, and H. Weissert (2004), Altered carbon cycling and coupled changes in Early Cretaceous weathering patterns: Evidence from integrated carbon isotope and sandstone records of the western Tethys, Earth Planet. Sci. Lett., 220, 69-82.

P. R. Bown, Department of Earth Sciences, University College London, Gower Street, London, WC1E 6BT, UK. (p.bown@ucl.ac.uk)

S. A. Robinson and T. Williams, LamontDoherty Earth Observatory, Columbia University, 61 Route 9W, Palisades, NY 10964 USA. (stuartr@1deo.columbia.edu; trevor@ldeo. columbia.edu) 